\title{
MECHANISTIC CONSIDERATIONS FOR HUMAN RELEVANCE OF CANCER HAZARD OF DI(2-ETHYLHEXYL) PHTHALATE
}

\author{
Ivan Rusyn ${ }^{1}$ and J. Christopher Corton ${ }^{2}$ \\ ${ }^{1}$ Department of Environmental Sciences and Engineering, University of North Carolina, Chapel \\ Hill, NC 27599, USA \\ ${ }^{2}$ Integrated Systems Toxicology Division, National Health and Environmental Effects Research \\ Laboratory, US Environmental Protection Agency, Research Triangle Park, NC 27711, USA
}

\section{Abstract}

Di(2-ethylhexyl) phthalate (DEHP) is a peroxisome proliferator agent that is widely used as a plasticizer to soften polyvinylchloride plastics and non-polymers. Both occupational (e.g., by inhalation during its manufacture and use as a plasticizer of polyvinylchloride) and environmental (medical devices, contamination of food, or intake from air, water and soil) routes of exposure to DEHP are of concern for human health. There is sufficient evidence for carcinogenicity of DEHP in the liver in both rats and mice; however, there is little epidemiological evidence on possible associations between exposure to DEHP and liver cancer in humans. Data are available to suggest that liver is not the only target tissue for DEHP-associated toxicity and carcinogenicity in both humans and rodents. The debate regarding human relevance of the findings in rats or mice has been informed by studies on the mechanisms of carcinogenesis of the peroxisome proliferator class of chemicals, including DEHP. Important additional mechanistic information became available in the past decade, including, but not limited to, sub-acute, sub-chronic and chronic studies with DEHP in peroxisome proliferator-activated receptor (PPAR) a-null mice, as well as experiments utilizing several transgenic mouse lines. Activation of PPARa and the subsequent downstream events mediated by this transcription factor represent an important mechanism of action for DEHP in rats and mice. However, additional data from animal models and studies in humans exposed to DEHP from the environment suggest that multiple molecular signals and pathways in several cell types in the liver, rather than a single molecular event, contribute to the cancer in rats and mice. In addition, the toxic and carcinogenic effects of DEHP are not limited to liver. The International Agency for Research on Cancer working group concluded that the human relevance of the molecular events leading to cancer elicited by DEHP in several target tissues (e.g., liver and testis) in rats and mice can not be ruled out and DEHP was classified as possibly carcinogenic to humans (Group 2B).

\footnotetext{
(C) 2011 Elsevier B.V. All rights reserved.
}

Corresponding author: Ivan Rusyn, MD, PhD, Dept. of Environmental Sciences and Engineering, University of North Carolina, Chapel Hill, NC 27599-7431, Phone/Fax (919) 843-2596, iir@unc.edu.

Disclaimer: The information in this document has been supported by the U.S. Environmental Protection Agency. It has been subjected to review by the National Health and Environmental Effects Research Laboratory and approved for publication. Approval does not signify that the contents reflect the views of the Agency, nor does mention of trade names or commercial products constitute endorsement or recommendation for use. The views stated herein are those of the authors and do not represent the views of the International Agency for Research on Cancer.

Publisher's Disclaimer: This is a PDF file of an unedited manuscript that has been accepted for publication. As a service to our customers we are providing this early version of the manuscript. The manuscript will undergo copyediting, typesetting, and review of the resulting proof before it is published in its final citable form. Please note that during the production process errors may be discovered which could affect the content, and all legal disclaimers that apply to the journal pertain. 


\section{General overview}

Exposure of the general population to DEHP is ubiquitous $[1,2]$ and occurs due to the use of consumer products, medical devices (blood bags and medical tubing), and intake from food and the environment (air, water and soil). Human data on cancer hazard of DEHP are largely inconclusive, because most studies lack appropriate exposure assessment and only indirect evidence for associations between various cancers and exposure to DEHP has been ascertained. The human database includes studies that infer possible associations of exposure to DEHP or other chemicals present in polyvinyl chloride-containing products with excess mortality from pancreatic [3, 4], testicular [5], and respiratory tract [6, 7] cancers, excess incidence of multiple myeloma [8], as well as increased risk of breast cancer [9] and pediatric hepatoblastoma [10-12].

The carcinogenicity database in animals conclusively shows that DEHP causes cancer of the liver in male and female mice and rats [13-16]. Additional potential target sites for DEHP carcinogenesis have also been reported. In a study in rats, a statistically significant incidence of pancreatic acinar cell adenomas was found in high-dose males [15]. In another study in rats, the incidence of Leydig cell tumors was increased, and was dose-related with early onset [16]. These findings are of potential importance as tumors of the exocrine pancreas are rare spontaneous tumors in experimental animals.

While the primary human health concern of exposure to phthalates is placed on early life exposures to DEHP and associated risks of reproductive and developmental effects, especially in males [17], this review's focus is on the cancer hazard of DEHP in liver and other tissues. We consider evidence from studies in humans, animals and in vitro experimental systems. Both cancer and relevant non-cancer toxic effects are described, and, where available, studies on the molecular mechanisms of such are emphasized. Even though the scientific debate regarding cancer hazard of DEHP is dominated by the data on liver effects, we include information on other potential target sites in both humans and animals.

\section{Toxic effects of DEHP in the liver}

\section{Human studies}

Several studies assessed potential hepatotoxicity of DEHP in humans. A study of 28 term infants with respiratory failure, 18 of whom received extracorporeal membrane oxygenation, a clinical procedure that results in a high intravenous dose of DEHP, and 10 untreated infants evaluated various clinical parameters of liver, pulmonary and cardiac function. Even though DEHP exposure was estimated to be as high as $2 \mathrm{mg} / \mathrm{kg}$ bw over 3-10 days (mean peak plasma concentration, $8 \mu \mathrm{g} / \mathrm{mL}$ ), all clinical parameters were found to be unaffected in treated infants [18]. However, a study that compared cholestasis in premature and newborn infants receiving parenteral nutrition through PVC-containing or - free infusion systems found that the use of polyvinylchloride tubing correlated strongly $(P=0.0004)$ with the development of cholestasis and that the incidence of cholestasis decreased from $50 \%$ to $13 \%$ after PVC-containing infusion systems were discontinued [19].

The liver cancer hazard of DEHP in humans may be inferred from the studies that suggest that a risk of hepatoblastoma, a rare childhood cancer of the liver, is considerably elevated in children who are born with very low birth weight [10]. Several additional publications have suggested that the duration of neonatal intensive care, which may have involved extensive use of PVC-containing medical devices, is significantly associated with both incidence [12] and severity (i.e., tumor stage) of hepatoblastoma [11]. 
Due to a very limited database on liver cancer hazard of DEHP in humans, evidence from studies with other chemicals that may act through similar molecular mechanisms may be considered as relevant. On the one hand, fibric acid analogues clofibrate, gemfibrozil and fenofibrate, drugs that act via activation of PPARa, have been used extensively in patients with dislipidemia and risk factors for coronary heart disease [20]. All of the published reports on the health outcomes of chronic administration of these pharmaceuticals in large human cohorts found no elevated risk of mortality from liver cancer [21-23]. In one of the cohorts $[24,25]$, the excess mortality due to a higher incidence of the malignant neoplasms of the "liver, gallbladder, and intestines" was reported in clofibrate-treated subjects; however, death rates among the clofibrate-treated group for cancer were similar to the official mortality statistics for individuals from the same area, the number of observed cases of gastrointestinal cancers was very small, and there was no difference among groups in a follow up analysis of the mortality trends in this cohort [23]. On the other hand, several ubiquitous environmental contaminants (e.g., chlorinated solvent trichloroethylene) are rapidly metabolized in rodents and humans to molecules that can act as PPARa ligands [26] and exposure to these compounds have been associated with liver toxicity and cancer. In rodents, sufficient evidence exists for hepatotoxicity [27,28] and hepatocarcinogenicity of trichloroethylene [29]. While some evidence exists of liver toxicity of trichloroethylene in humans, as assessed from liver function and other tests, the data are considered to be inadequate for making conclusions regarding causality due to great difficulty with attributing exposure to a particular environmental chemical to disease [reviewed in detail in [30]]. The evidence is also limited for trichloroethylene and liver and biliary tract cancer [31] mainly because only cohort studies are available; most of these studies have small numbers of cases resulting in wide confidence intervals on the relative risk estimates; and difficulties in establishing exposure-response relationships [detailed descriptions of the individual studies and the meta-analysis may be found in the Environmental Protection Agency's toxicological review of tricholorethylene publicly available at http://www.epa.gov/iris/subst/0199.htm].

\section{Primate studies}

Subchronic liver toxicity has been reported in non-human primates who have been subject to chronic transfusions through DEHP-containing PVC tubing. Abnormal liver function (e.g., bromosulfophthalein clearance) and cholestasis have been reported in rhesus monkeys in chronic experiments that mimicked conditions of patients undergoing repeated blood or platelet transfusions through PVC-containing tubing, an effect absent using polyethylene containers [32]. The average cumulative amount of DEHP infused in 1 year was $69.3 \mathrm{mg}$, or $21.3 \mathrm{mg} / \mathrm{kg} / \mathrm{day}$ which the authors found to be comparable or even lower than that in humans on chronic transfusion therapy. A subsequent study in rhesus monkeys by the same group evaluated hepatic function and liver histology up to 26 months after cessation of transfusions [33]. It was reported that abnormal liver function tests and histologic abnormalities (e.g., disturbances of hepatic architecture, the presence of round-cell infiltration, and multinucleated giant cells) in liver biopsies persisted throughout the transfusion study and the follow-up period. While these studies implicate DEHP as a potential toxic ingredient of plastic medical devices, these associations need to be further verified. Similar liver toxic effects of DEHP appear not to be observed in rodents and may be a factor of exposure route (intravenous vs dietary) or comprise another set of important species differences. DEHP $(500 \mathrm{mg} / \mathrm{kg} /$ day $)$ exposure in young adult male cynomolgus monkeys revealed no distinctive treatment-related effects in the liver [34].

\section{Rodent studies}

Liver toxicity (defined here as tissue damage; hepatomegaly and other effects are discussed extensively in other sections below) of DEHP has been reported in some, but not all studies 
in rats and mice. Dietary administration of DEHP (2\%) to mice for 10 days resulted in liver dysfunction as evidenced from histological observations and serum analysis [35]. In a 104week dietary exposure study to DEHP in B6C3F1 mice [14], an increase in a number of signs of liver damage have been reported. Hepatocyte pigmentation, increased cytoplasmic eosinophilia and chronic inflammation were observed in all male and female mice in the $6000 \mathrm{ppm}$ group (no signs of these histopathological changes were found in control and lower dose groups). In a 104-week dietary feeding study in F344 rats, significant increases in the incidence of Kupffer/hepatocyte pigmentation was reported in male and female rats at $12500 \mathrm{ppm}$ dose, and of spongiosis hepatis in male rats at 2500 and $12500 \mathrm{ppm}$ [15].

Several other studies reported no signs of liver injury [36-38]. Furthermore, even though there are no studies evaluating cholestasis due to DEHP in rats or mice for comparison with human and primate studies, other peroxisome proliferators are known to have a protective effect against cholestasis in rodents. For example, cholestasis was observed in bezafibratefed PPARa-null, but not wild type mice [39].

Consistent findings of liver carcinogenicity of DEHP were reported from several independent chronic studies in mice and rats of both sexes [40,41]. The incidence of liver tumors is known to be dependent both on dose of DEHP and duration of exposure. A study which compared the carcinogenic potency of DEHP in wild type and PPARa-null mice [38] reported that after 24 months of feeding the diet containing $0.05 \%$ DEHP, a greater number of adenomas of the liver was observed in PPARa-null mice. Also, one hepatocellular carcinoma and one cholangiocellular carcinoma were observed in PPARa-null, but not wild type mice for this dose group.

\section{Hepatocyte-specific effects of DEHP in the liver}

The landmark paper by Klaunig et al [42] defined the "PPARa mode of action" and concluded that it exclusively mediates the carcinogenicity of DEHP and other related compounds. A number of reviews have considered the evidence for receptor-mediated and independent molecular events in the development of liver and other tissue tumors induced by peroxisome proliferators, including DEHP, as well as their relevance to human health assessment [43-45]. These various perspectives have contributed greatly to the understanding of the issues pertinent to the interpretation of rodent data on DEHP and related chemicals to characterize the potential for human cancer hazard.

\subsection{Effects of DEHP on PPAR activation}

Phthalates, including DEHP, are activators of nuclear receptors PPARa, $\beta$ and $\gamma$ [46-49].

Human studies-No studies could be found which showed evidence that DEHP activates PPARa in human liver. In vitro, trans-activation assays were used to assess the activation potential of DEHP, MEHP and 2-ethylhexanoic acid for either the full length PPAR subtype $[50,51]$ or hybrid transcription factors consisting of the PPAR ligand binding domain cloned to the glucocorticoid receptor [52] or GAL4 [53] DNA binding domains. DEHP was not able to activate human PPARa or human PPAR $\gamma$ [50]; however, several studies showed that all three human PPAR subtypes were activated by MEHP [51-53]. In addition, both human PPAR $\gamma$ isoforms $\gamma 1$ and $\gamma 2$ were activated by MEHP [54]. The DEHP metabolite 2ethylhexanoic acid weakly activated human PPARa but not human PPAR $\gamma$ [50]. No studies have examined the activation of human PPAR $\beta$ by DEHP or 2-EH.

Lapinskas et al. [49] determined whether phthalate esters interact directly with human PPARa or $\gamma$ using the scintillation proximity assay. The $\mathrm{K}_{\mathrm{i}}$ for the MEHP to bind to the a and $\gamma$ subtypes were $15 \mathrm{uM}$ and $12 \mathrm{uM}$, respectively. DEHP was negative in this assay (i.e., $\mathrm{K}_{\mathrm{i}}>150 \mathrm{uM}$ ). The PPAR $\beta$ subtype was not examined. In a recent study [55] DEHP was 
examined for the ability to activate several response elements (cis assays) in a multiplex human response element transactivation assay in the human HepG2 cell line. In addition, a modification of the approach was used to generate the human ligand-binding domain of nuclear receptors expressed as a chimera with the yeast GAL4 DNA-binding domain that activated a $5 \mathrm{X}-\mathrm{UAS}_{\mathrm{G}}$-TATA promoter linked to a reporter sequence (trans assay) [56]. DEHP was shown to significantly activate PPARa and PPAR $\gamma$ : PPAR $\gamma \_$TRANS $\left(E_{50}=46\right.$ $\mu \mathrm{M})$, PPRE_CIS $\left(\mathrm{EC}_{50}=48 \mu \mathrm{M}\right)$, PPARa_TRANS $\left(\mathrm{EC}_{50}=50 \mu \mathrm{M}\right)$. PPAR $\beta$ TRANS assay was negative for DEHP.

Experimental systems-In vivo, DEHP has little effect on mRNA levels of PPARa in rats or mice [57]; however, the increase in PPAR transactivation activity by DEHP and its metabolites is well established. The DEHP metabolite MEHP activates mouse PPARa, mouse PPAR $\gamma$ and to a lesser extent, mouse PPAR $\beta$ in trans-activation assays [50-52, 54]. In addition, both mouse PPAR $\gamma$ isoforms $\gamma 1$ and $\gamma 2$ were activated by MEHP [54]. 2ethylhexanoic acid (2-EH) weakly activated mouse PPARa, $\beta$ and $\gamma$ [49, 52]. In one study 2 -EH failed to activate mouse PPAR $\gamma$ [50]. DEHP itself is a weak activator of PPARa and PPAR $\gamma$ although it cannot be ruled out that the active species was a metabolite of DEHP $[49,52]$. DEHP did not activate mouse PPAR $\beta[49,52]$.

Species comparisons-Important species differences in expression and molecular signalling for PPARa have been reported. Mice and rats express PPARa at high levels in liver, whereas PPARa is expressed at a lower level in human liver [58]; however, expression of hPPARa has not been determined in a sufficient number of samples to unequivocally conclude that all populations express less PPARa than responsive rodents. In one study the expression of hPPARa protein in one of six humans appeared to approach the levels found in mouse livers [59], yet the hPPARa protein expression in this study was not normalized to housekeeping or loading controls that would help to evaluate whether the proteins in the sample were intact. In a side-by-side comparison of expression in liver, mice had $\sim 10$-fold more PPARa mRNA expression than guinea-pigs and $\sim 3$-fold more than Syrian hamsters [60]. No differences in constitutive PPARa mRNA expression was reported between CD-1 mice and Sprague-Dawley rats, but a lower level of expression ( 25\% the level of mouse) was found in marmosets (Calithrix jacchus) [57].

There is evidence that human and rodent PPARa differ in their ability to be activated by PPARa agonists, as would be expected given that the amino acid sequences within the ligand binding domains differ between species. The mouse and rat PPARa ligand binding domains are 94\% similar to that of the human PPARa [48, 61]. Higher concentrations of MEHP are required for activation of human PPARs to the same levels as the corresponding mouse receptor $[50,51,53]$.

A truncated human PPARa variant has been reported, and it was suggested that the truncated form may be responsible for differential responses between species. This truncated form, identified in several laboratories and called hPPARa-8/14 [62], hPPAR ${ }_{S V}$ [58], $\mathrm{PPARa}_{\text {tr }}$ [63], and PPARa2 [64], lacks exon 6 due to alternative splicing, resulting in an altered hPPARa lacking the ligand binding domain. In in vitro transactivation assays, this form acts as a dominant negative, inhibiting the ability of the wild-type receptor to activate transcription, possibly by titrating out limiting amounts of co-activators such as C/EBP binding protein/p300 [63]. The level of the truncated hPPARa mRNA ranges from 10\% to $50 \%$ of full-length hPPARa mRNA $[58,63,64]$. One study concluded that the level of the truncated form does not correlate with responsiveness to PPARa agonists [64]; however, this study only measured primary human hepatocyte mRNA levels of the ACO gene, not an optimal biomarker of hPPARa activity given that this gene does not appear to be regulated in the same manner as the rodent gene by PPARa [180]. 


\subsection{Effects of DEHP on markers of PPAR activation}

PPARa activation in the liver may also be characterized indirectly by assessing: (1) increases in the size and/or numbers of peroxisomes in cells; (2) increases in acyl-CoA oxidase (ACO) expression, protein or activity; (3) increased expression, protein levels or activity of CYP4A protein, an $\omega$-lauric acid hydroxylase (LAH); and/or (4) increases in the levels of carnitine acyl-CoA transferase (CAT). Some of these markers have been shown to be activated even in the absence of PPARa, i.e., in PPARa-null mice exposed to peroxisome proliferators [65]; thus, the results from these indirect assays should be interpreted with caution if no direct evidence for changes in PPARa activity is available.

Human studies - No study assessed markers of PPARa activation after administration of DEHP to humans; however, studies are available from people who may have been exposed to DEHP and other agents leaching from plastics used in medical devices. Dialysis patients were evaluated for evidence of liver peroxisome proliferation in biopsy samples [66, 67]. Based on a subjective ultrastructural evaluation of one subject, no effect was seen after one month of dialysis. However, in a liver biopsy from one subject after 12 months of dialysis, an increased number of peroxisomes was reported. Others have suggested that more cautious evaluation, including objective measurements, increased numbers of biopsy intervals, and appropriate controls, would be needed to determine conclusively whether peroxisome proliferation due to DEHP occurs in dialysis patients [68].

Experimental systems-In young adult male cynomolgus monkeys exposed to DEHP $(500 \mathrm{mg} / \mathrm{kg} /$ day) by intragastric intubation for 14 consecutive days, no effect on body weight, liver weights, histological observations in the liver, kidney, or testes, or markers for peroxisomal proliferation were observed [34]. When male and female marmosets (5-6 per group) were exposed to DEHP $(0,100,500$, or $2500 \mathrm{mg} / \mathrm{kg})$ by daily oral gavage for 65 weeks from weaning ( 3 months age) to sexual maturity (18 months), no changes were observed in cyanide-insensitive palmitoyl-CoA $\beta$ oxidation in males [69]. However, large variability in activity of some peroxisomal enzymes was observed in treated females, especially at the $500 \mathrm{mg} / \mathrm{kg}$ dose. For lauric acid $\omega$-1-hydrolase activity, females exhibited dose-related increases in comparison to controls that were statistically significant at $500 \mathrm{mg} /$ $\mathrm{kg}$.

In the rat, DEHP increases relative liver weights, markedly induces activity of hepatic peroxisomal enzymes, and increases microsomal cytochrome P450 content [70, 71]. Ultrastructural examination showed marked peroxisome proliferation and a dilation of the smooth and rough endoplasmic reticulum. DEHP is a hypolipidemic agent, as serum triglyceride levels were reduced. In mice, DEHP had effects similar to those found in rats, albeit slightly weaker in magnitude [71].

The effects of DEHP in the rat and mouse were dose-dependent [41, 72]. Male and female Fischer 344 rats and $\mathrm{B} 6 \mathrm{C} 3 \mathrm{~F}_{1}$ mice were fed DEHP for up to 13 weeks [41]. In rats fed $12500 \mathrm{ppm}$ DEHP, there was an increase in hepatic peroxisomal $\beta$-oxidation activity after one, two and 13 weeks administration. In mice fed 10000 and 17500 ppm DEHP, there was an increase in hepatic peroxisomal $\beta$-oxidation activity after one, two and 13 weeks administration. In mice fed $1000 \mathrm{ppm}$ DEHP, there was no statistically significant increase in hepatic peroxisomal $\beta$-oxidation activity after one, two or 13 weeks administration. Peroxisomal enzyme induction was also observed in the kidney after exposure to DEHP [73].

A correlation between the enzymatic marker of the peroxisomal fatty acid $\beta$-oxidation cycle and changes in peroxisome morphometry is a well-established phenomenon, demonstrating that peroxisomal cyanide-insensitive palmitoyl-CoA oxidation is a good marker for 
peroxisome proliferation in rodent liver [72]. However, DEHP has been shown to affect expression of genes other than those involved in peroxisomal or microsomal metabolism. Microarray analysis of male C57BL/6 mice treated with DEHP (1.0\% in the diet) for 13 weeks identified 51 DEHP-regulated genes in the liver involved in peroxisome proliferation, xenobiotic detoxification, oxidative stress response, immune function, steroid hormone metabolism, testis development, and pheromone transport [74]. In Currie et al. [75], B6C3F1 male mice were treated with DEHP $(1150 \mathrm{mg} / \mathrm{kg} /$ day, daily oral gavage $)$ and gene expression levels were measured 2, 8, 24, and 72 hours after the initial dose. A robust increase in Cyp4a10 expression was observed from the earliest time point sampled. A coordinate induction of genes involved in fatty acid metabolism was confirmed by the overrepresentation of Gene Ontology terms and PANTHER and GenMAPP pathways involved in metabolism of lipids (e.g., acyl-CoA metabolism, fatty acid $\beta$-oxidation, pantothenate and CoA biosynthesis, or coenzyme metabolism).

Dostal et al. [76] compared effects of DEHP in neonatal, adolescent and adult rats. Groups of male Sprague-Dawley rats were given 0, 10, 100, 1000 or $2000 \mathrm{mg} / \mathrm{kg} / \mathrm{day}$ DEHP by gavage for 5 days, beginning at the age of $6,14-16,21,42$ or 86 days. After two doses of $2000 \mathrm{mg} / \mathrm{kg} / \mathrm{bw}$ per day, virtually all pups in the three youngest age groups died, whereas six- and 12-week-old rats showed significantly decreased body weight but no fatalities. Five daily doses of $1000 \mathrm{mg} / \mathrm{kg} / \mathrm{bw}$ per day caused significant decreases in body weight gain in one-, two- and three-week-old rats. Absolute and relative liver weights were significantly increased at $100 \mathrm{mg} / \mathrm{kg} / \mathrm{day}$ in all age groups (except for 1-week-old rats) and in all age groups at higher dose levels. Morphological examination revealed increased peroxisome proliferation in neonatal as well as in adult rats. The activities of cyanide-insensitive palmitoyl-CoA oxidase and carnitine acetyltransferase were increased in a dose-dependent manner in all age groups. The activities of these enzymes were similar in control rats of all ages.

Transfer of DEHP through milk was evaluated in female Sprague-Dawley rats given a total of five oral doses of $2000 \mathrm{mg} / \mathrm{kg} /$ day by gavage on days $2-6,6-10$ or 14-18 of lactation [77]. The body weights of lactating rats and of their suckling pups were significantly reduced at all time points. Food consumption was reduced in the dams dosed on days 14-18. Relative liver weights were increased in the lactating dams at all three stages of lactation but not in the suckling pups. The hepatic peroxisomal enzyme activities (cyanide-insensitive palmitoyl-CoA oxidase and carnitine acetyltransferase) were increased five- to eight-fold in treated dams at all three stages of lactation. Two-fold increases in these enzyme activities were also observed in pups suckling the treated dams. Hypolipidaemia was observed in treated lactating rats at all 3 stages of lactation. In a study that used Fischer 344 rats, exposure of lactating females to $\operatorname{DEHP}(0,0.5,1,2.5$ or $5 \mathrm{~g} / \mathrm{kg}$ per day) by oral gavage from birth through lactation day 21, similar effects in the pups and dams were observed [78]. No pup survived exposure to doses of $2.5 \mathrm{~g} / \mathrm{kg}$ per day. Pup growth was impaired at the two lowest doses. In the liver, cyanide-insensitive palmitoyl-CoA oxidase activity was increased to a similar extent in both pups and adult females.

A 13-week study with DEHP (100, 500 or $2500 \mathrm{mg} / \mathrm{kg} /$ day, gavage) in male and female marmosets significant suppression was observed of body weight gain in male marmosets given $2500 \mathrm{mg} / \mathrm{kg} /$ day [79]. No effect was found on relative liver weight, morphological features in the livers, hepatic cyanide-insensitive palmitoyl-CoA oxidation, or carnitine acetyltransferase activity. Ultrastructural examination of the liver did reveal small increases in mean peroxisomal volume in male marmosets given 500 or $2500 \mathrm{mg} / \mathrm{kg}$ DEHP.

Induction of peroxisomal enzymes by DEHP metabolites was also observed in vitro with isolated cultured rat and mouse hepatocytes. MEHP and EH increased carnitine 
acetyltransferase activity several fold in hepatocytes from male Wistar or Sprague-Dawley rats $[80,81]$. Another DEHP metabolite, mono(2-ethyl-5-oxohexyl)phthalate, was shown in vitro to inhibit fatty acid oxidation at the site of transport across the mitochondrial inner membrane with a marked species difference. This finding supports the idea that induction of peroxisome proliferation could be due to an initial biochemical lesion of fatty acid metabolism [82].

Species comparisons-A number of studies conducted a direct species comparison of the effects of DEHP on markers of PPARa activation. A comparative study of rats, mice and guinea-pigs that were fed DEHP (2\%) for two weeks found that hepatic cyanideinsensitive palmitoyl-CoA oxidation activity was significantly increased in rats and mice, but not in guinea-pigs [83]. Similar observations of non-responsiveness of guinea pigs as compared to rats were reported in a 4-day study with DEHP (950 mg/kg/day, gavage) [84]. Significant increases in liver weights and hepatic $\beta$-oxidation activity were observed in the rats but not the guinea-pigs. Administration of DEHP (25-1000 mg/kg/day by gavage) for 14 days to male Sprague-Dawley rats and male Syrian hamsters produced dose-related increases in relative liver weights and activites of both hepatic cyanide-insensitive palmitoyl-CoA oxidation and carnitine acetyltransferase in both rats and hamsters, yet the hamsters were much less responsive [85]. In the same study, rats and hamsters were treated with MEHP (500 mg/kg bw/day). Similar to the difference observed with DEHP, MEHP produced a greater increase in relative liver weight and a greater stimulation of enzyme activities in rats compared to hamsters.

There are several published reports comparing in vivo responses to DEHP in rats or mice with non-human primates. DEHP (2000 mg/kg bw/day, gavage) was administered for 14 days to male and female Wistar rats and male and female marmosets [86]. Marmosets were also treated with DEHP (1000 mg/kg bw/day) by daily intraperitoneal injection for 14 days. In rats, there were increases in relative liver weight, $\omega$-lauric acid hydroxylation and hepatic peroxisome proliferation, as demonstrated by ultrastructural peroxisome examination and increased cyanide-insensitive palmitoyl-CoA oxidation and. No such effects were observed in marmosets given DEHP by either oral or intraperitoneal administration. In a recent study, male mice (CD-1), rats (Sprague-Dawley), and marmosets (Callithrix jacchus) were treated with DEHP by gavage [57]. Mice and rats were treated with $0,1.25$ and $2.5 \mathrm{mmol} / \mathrm{kg}$ DEHP for 2 weeks, while marmosets were exposed to $0,0.25,1.25$ and $6.25 \mathrm{mmol} / \mathrm{kg}$ DEHP for 15 months. Liver to body weight ratios increased in rats and mice in both treatment groups. No effect on relative liver weight was observed in marmosets. Liver concentrations of MEHP (measured at the end of the treatment period) increased in a dose-dependent manner in all species tested, yet it was $\sim 3$-fold lower in the marmoset compared to rats and mice when similar dose-groups were compared. Induction of liver peroxisomal enzymes was detected in DEHP-treated rats and mice, but not marmosets. A study that compared male Fischer 344 rats and cynomolgus monkeys treated with DEHP (rats: diet with 100-25000 ppm for 21 days; monkeys: daily gavage with 100 or $500 \mathrm{mg} / \mathrm{kg}$ bw for 25 days) reported a dose-related increase in relative liver weights, and enzymatic markers and ultrastructural evidence (subjective evaluation) of hepatic peroxisome proliferation in rats [87]. No effect on relative liver weights, activities of cyanide-insensitive palmitoyl-CoA oxidation, carnitine acetyltransferase and lauric acid 12-hydroxylase, or abnormalities in light or electron microscopic examination of liver sections were observed in cynomolgus monkeys.

In cultured hepatocytes, effects of DEHP metabolites were also compared across different species. While rat hepatocytes respond to treatment with MEHP by concentration-dependent induction of cyanide-insensitive palmitoyl-CoA oxidation, no such effect was observed in guinea-pig [88-90], Syrian hamster [89], New Zealand rabbit [90], or cynomolgus monkey [90] hepatocytes. Treatment with either 2-ethylhexanol or 2-ethylhexanoic acid for 72 hours 
produced a concentration-dependent induction of cyanide-insensitive palmitoyl-CoA oxidation in rat and mouse, but not guinea-pig or marmoset hepatocytes [91]. Goll et al. [92] examined the effects of various peroxisome proliferators including DEHP on peroxisomal enzyme activities, apoptosis and DNA synthesis in rat $\mathrm{FaO}$ and human $\mathrm{HepG} 2$ hepatoma cell lines. Both growing and confluent cultures were treated for 48 or 72 hours. DEHP increased peroxisomal enzyme activity in rat $\mathrm{FaO}$ cells but not in human $\mathrm{HepG} 2$ cells. In Hasmall et al. [84], rat hepatocytes in vitro, treated with MEHP $(250,500$ and $750 \mu \mathrm{M})$ exhibited increased peroxisomal $\beta$-oxidation. In contrast, there was no response of human hepatocytes at these concentrations.

\subsection{Effects of DEHP on PPAR-independent receptor-mediated events}

Human studies-All of the available studies have been performed using human cells in vitro.

The estrogenic activity of DEHP was investigated in competitive ligand-binding assays, yeast and mammalian gene expression assays, and in a uterotrophic assay. DEHP did not compete for estrogen receptors (ER) or induce luciferase activity in transfected MCF-7 cells or stably transfected HeLa cells [93]. Ghisari and Bonefeld-Jorgensen [94] investigated in vitro estrogenic activities of a range of widely used plasticizers and phenols, including DEHP. The estrogenic activities of the compounds were assessed in human breast cancer MVLN cells, stably transfected with an estrogen receptor element luciferase reporter vector. Furthermore, the combined effect of a multicomponent mixture of six plasticizers was evaluated for its estrogenic activities. The chemicals were tested in an ER trans-activation assay alone and upon co-treatment with $25 \mathrm{pM} \mathrm{E2}$. DEHP antagonized the $17 \beta$-estradiol induced $E R$ function $\left(E_{50}=84 \mu \mathrm{M}\right)$. No significant activity was observed for DEHP in the ER trans-activation assay. Takeuchi et al. [95] characterized the activities of human estrogen receptor $\alpha(\mathrm{hERa})$ and human estrogen receptor $\beta$ (hER $\beta$ ) in the presence of 22 phthalates, including DEHP and MEHP, using reporter gene assays. DEHP, but not MEHP activated hERa. Neither DEHP nor MEHP activated hER $\beta$. DEHP but not MEHP had antagonistic effects on ER $\beta$. Kang \& Lee [96] reported increased expression of ER $\beta$ after DEHP exposure $(3.0 \mu \mathrm{g} / \mathrm{ml})$ of the human breast cancer cell line MCF-7.

DEHP and its metabolite MEHP do not bind to the human androgen receptor (AR) [97]. It was also reported that neither DEHP nor MEHP possessed human AR antagonism [95]. DEHP did not affect human AR activation using chemically activated luciferase gene expression bioassays in transiently transfected Chinese Hamster Ovary (CHO-K1) cells [98].

DEHP was shown to activate human pregnane $X$ receptor (PXR)-mediated transcription [99]. Transfection assays were performed with a human PXR expression plasmid and a reporter plasmid containing the XREs in the CYP3A4 gene promoter in HepG2 cells. This study indicates that DEHP may be an inducer of the CYP3A4 gene through PXR, and may influence the metabolism of endogenous steroids, drugs, and other xenobiotics. The same group also tested the hypothesis that leaching of DEHP during parenteral chemotherapy for cancer patients may facilitate PXR mediated MDR1 expression in various tissues, including cancer cells, promoting drug resistance [100]. The effect of DEHP on PXR-mediated transcription of the MDR1 gene was studied in the human colon adenocarcinoma-derived cell line, LS174T, which endogenously express PXR. DEHP increased PXR-mediated transcription of the MDR1 gene in luciferase-reporter assays. The induction by DEHP was abrogated when a reporter plasmid containing a mutated DR+4 motif in the XRE was used. In a mammalian two-hybrid assay, DEHP recruited steroid receptor co-activator-1 to the ligand-binding domain of PXR. Using real-time reverse transcriptase-PCR, DEHP increased MDR1 gene expression in a dose-dependent manner. The data support activation of the MDR1 gene by DEHP through PXR. The ability of DEHP and MEHP to induce PXR- 
mediated transcription of the CYP3A4 promoter in a dose-dependent fashion was also shown using HepG2 cells [101]. Co-exposure to either MEHP or DEHP and dexamethasone (Dex) resulted in enhanced CYP3A4 promoter activity. This induction was abrogated by both the GR antagonist RU486 and GR small interfering ribonucleic acid. CYP3A4 protein was highly inducible by Dex and DEHP co-administration in human primary hepatocyte cultures. Enhanced 6 $\beta$-hydroxytestosterone formation in Dex and DEHP or MEHP cotreated human primary hepatocytes confirmed CYP3A4 enzyme induction. DEHP was shown to activate human PXR $\left(\mathrm{EC}_{50}=2.5 \mu \mathrm{M}\right)$ in stably transfected cells, HGPXR cells, derived from HeLa cells and expressing luciferase under the control of a chimeric hPXR [102]. DEHP was also able to induce CYP3A4 expression in two preparations of primary cultured human hepatocytes at $10 \mu \mathrm{M}$ (8- and 38-fold).

The ability of DEHP and/or MEHP to activate human constitutive androstane receptor (CAR) and induce expression of its target genes has been shown in a number of studies. DEHP was able to induce CYP2B6 expression, an indication of CAR activation in two preparations of primary cultured human hepatocytes at $10 \mu \mathrm{M}$ (2-and 4-fold). In humans, a novel splice variant of CAR (CAR2) results in a 4 amino acid insertion in the ligand binding domain. The CAR 2 comprises approximately $30 \%$ of the total CAR transcript levels in human hepatocytes [103]. The CAR2 transcripts are not generated in mice, rats, and marmosets. CAR2 was shown [104] to be potently activated in cells transfected with CAR2 by DEHP $(0.098 \mu \mathrm{g} / \mathrm{ml})$ and weakly by MEHP $(2.8 \mu \mathrm{g} / \mathrm{ml})$. In the same study, primary human hepatocyte cultures from 3 donors, cultured in such a way to preserve differentiation, had very different responses to CAR-responsive induction of CYP2B6 and CYP3A4. The DEHP concentrations that induced these enzymes (in the absence of cytotoxicity) was 3.9 $\times 10^{-3} \mu \mathrm{g} / \mathrm{ml}, 19.5 \mu \mathrm{g} / \mathrm{ml}$, and $0.39 \mu \mathrm{g} / \mathrm{ml}$ for the 3 donors. In addition, induction of CYP2B6 gene expression indicative of CAR activation in primary human hepatocyte cultures (culture conditions not cited) was increased in cultures from two patients exposed to $19.5 \mu \mathrm{g} / \mathrm{ml}$ DEHP [105]. In the multiplex transcription factor assay described above [56], DEHP significantly activated human PXR (PXRE_CIS $\left(\mathrm{EC}_{50}=37 \mu \mathrm{M}\right)$, PXR_TRANS $\left.\left(\mathrm{EC}_{50}=38 \mu \mathrm{M}\right)\right)$ and human CAR $\left(\mathrm{CAR} \_\right.$TRANS $\left.\left(\mathrm{EC}_{50}=50 \mu \mathrm{M}\right)\right)$. In a study that used a pooled human hepatocyte sample from multiple donors, DEHP was tested for its ability to increase transcription of several genes associated with activation of PPARa, CAR, PXR, FXR and AhR [55]. DEHP significantly increased the expression of only the CAR responsive gene CYP2B6 at the 3 time points (6, 24 and $48 \mathrm{hrs)} \mathrm{studied.} \mathrm{The} \mathrm{interaction} \mathrm{of}$ alternatively spliced human CARs and PXR with a range of suspected endocrine disruptors, including DEHP, was studied using COS-1 cells [106]. DEHP had EC 50 values for activation of CAR2 and PXR of 0.1 and $3.8 \mu \mathrm{M}$. DEHP did not activate another CAR isoform (CAR3) which possesses a 5 aa insertion in the ligand binding domain. Mutation analysis of CAR2, in silico modeling, and ligand docking studies suggested that the SPTV amino acid insertion of CAR2 creates a unique ligand-binding pocket that selectively recognizes phthalates.

DEHP was shown to weakly induce human aryl hydrocarbon receptor (AhR) activity, reaching 1.75-fold above the solvent control at the highest concentration tested $(100 \mu \mathrm{M})$ using chemically activated luciferase gene expression bioassays in recombinant mouse Hepa1.12cR cells [98]. The ability of MEHP to induce CYP1A1, a known AhR target gene, was studied in human cell lines CaCo-2 (derived from colon adenocarcinoma), HepG2 (hepatoma), A549 (lung adenocarcinoma), as well as primary human keratinocytes [107]. The induction specifically involved PPARa and required 2 PPRE sites that were located within the CYP1A1 promoter. Whether this also occurs in normal human hepatocytes is yet to be established. CYP1A1 is responsible for bioactivation of several environmental procarcinogens, and it was reported that DEHP and other peroxisome proliferators enhance DNA adduct formation in rat liver when co-administered with benzo[a]pyrene [108]. Thus, 
the fact that MEHP is capable of regulating CYP1A1 in PPARa-mediated manner in human cells may have significant implications; however, others have shown that another peroxisome proliferator, clofibrate, inhibits expression of CYP1A1 and CYP1A2 in rat liver cells [109].

Experimental systems-Tomonari et al. [69] treated male and female marmosets daily with $0,100,500$, or $2500 \mathrm{mg} / \mathrm{kg}$ DEHP by oral gavage for 65 weeks from weaning ( 3 months age) to sexual maturity (18 months) and examined serum hormone levels and several enzyme activities. Although the authors note no obvious treatment related changes in testosterone levels in any treatment groups, there were large variations in individual values (serum testosterone in males varied over 100-fold). Significantly higher estradiol levels were recorded in all female marmosets by week 65 in the $500 \mathrm{mg} / \mathrm{kg}$ group. For females, increased ovarian and uterine weights were observed in higher dose groups (500 and 2500 $\mathrm{mg} / \mathrm{kg}$ body weight). For testis, the authors report that there were no treatment related differences in GSH content, or differences in the activities of SDH (sorbitol dehydrogenase), $\gamma$-GT ( $\gamma$-glutamyl transpeptidase), and GSH-Px (glutathione peroxidase). There was a decrease of SDH activity of $\sim 15-20 \%$ for the dosed groups that was not statistically significant but the low number of animals limited the power of the study to detect a change. There was also a similar magnitude of increased $\gamma$-GT that was not statistically significant and a $~ 30 \%$ decrease in total glutathione (GSH and GSSG) was also observed in all groups that was not statistically significant. However, GST activity and zinc content in the 100 and $500 \mathrm{mg} / \mathrm{kg}$ treated groups were significantly reduced. For testosterone $6 \beta$-hydrolase activity (CYP3A) in the liver, females were reported to have increased levels at 500 and $2500 \mathrm{mg} / \mathrm{kg}$ exposure levels but only the changes observed at the $2500 \mathrm{mg} / \mathrm{kg}$ dose group were statistically significant. This activity was increased in all dose groups for males but was not statistically significant ( $~ 85 \%$ at $100 \mathrm{mg} / \mathrm{kg}$ dose for $\mathrm{nmol} / \mathrm{g}$ liver $/ \mathrm{min})$.

An effect of DEHP on estrogen metabolism has been reported [110]. Male Fischer 344 rats fed diets containing 1.2\% DEHP for 4, 8 or 16 weeks had significantly increased serum estradiol levels. This was explained by the observation that these rats showed significant loss of hepatic activity of a major male estrogen-metabolizing enzyme, estrogen 2hydroxylase, and a male-specific estrogen-sequestering protein.

Wong et al. [74] reported a treatment-related suppression of hormone metabolizing $3 \beta$ hydroxysteroid dehydrogenase V (HSD3b5), in the livers of male C57B6 mice exposed to DEHP. Northern blots showed HSD3b5 mRNA levels decreased dramatically upon one day exposure to $2.0 \%$ dietary DEHP and were nearly undetectable after one week of treatment. Another mouse $3 \beta$-hydroxysteroid dehydrogenase (HSD3b4), predominantly expressed in kidneys was also down-regulated by DEHP in the liver. After 4 weeks of exposure to DEHP, HSD3b5 and HSD3b4 mRNAs were reduced in a dose-dependent manner. DEHP treatment had a greater effect on HSD3b5 levels than HSD3b4.

Recent in vivo studies in PPARa-null, PPARa humanized transgenic, and hepatocytespecific constitutively activated PPARa transgenic mice suggest that several PPARaindependent molecular signals and multiple pathways may be activated by peroxisome proliferators, including DEHP.

Transgenic mice with hepatocyte-specific constitutively active PPARa were developed and observed for up to 11 months of age [111]. In the absence of treatment, these transgenic mice exhibited various responses that mimic wild-type mice treated with peroxisome proliferators. These effects included a significant decrease in serum fatty acids, and numerous liver effects: hepatomegaly, hepatocyte hypertrophy, increased rate of cell proliferation, marked induction of PPARa target genes encoding fatty acid oxidation 
enzymes and increased accumulation of triglycerides. Even though these phenotypic changes were similar (and of comparable magnitude) to those induced in wild-type mice by a peroxisome proliferator WY-14,643 (0.1\% w/w diet), no liver tumors were detected in untreated transgenic mice by 11 months of age even though all WY-14,643-treated wildtype mice developed liver tumors.

Another study used hepatocyte transplantation to generate chimeric livers composed of PPARa-null and -positive hepatocytes in PPARa-null or -positive mice [112]. The authors examined the relationship between PPARa status and the hepatocyte's ability to proliferate in response to WY-14,643 in vivo. When treated with WY-14,643 for 7 days, both PPARanull and -positive hepatocytes in chimeric livers displayed elevated DNA synthesis regardless of host receptor status, as long as at least some hepatocytes contained the receptor. These findings suggest that the mitogenic response to peroxisome proliferators does not require the presence of active PPARa in all hepatocytes.

Two studies used a transgenic mouse line that overexpresses human PPARa in a PPARa -null mouse [113] also called PPARa humanized mice. These mice have been used for subchronic studies with WY-14,643 and fenofibrate [113], and a chronic feeding study with Wy-14, 643 [114]. In these studies, PPARa-humanized mice did not exhibit hepatocellular proliferation, or liver tumors when treated with peroxisome proliferators; however, induction of typical markers of fatty acid $\beta$-oxidation were observed. These mouse models have not been evaluated with DEHP.

PPARa-null mice and corresponding wild-type mice (C57BL/6J strain) were treated with DEHP $(0,20$ or $200 \mathrm{mg} / \mathrm{kg}$ day) for 21 days by gavage [105]. While this study did not report on liver weight or liver histopathology, gene expression profiling was performed on liver tissues and the authors reported that several prototypic CAR target genes were induced by DEHP in PPARa-null mice. In addition, Cyp1a1, a marker gene for AhR activation, was increased in PPARa-null mice but not wild-type mice.

Fan et al. [115] reported that in male SV129 wild type and PPARa-null mice fed DEHP $(0.6 \%)$ in diet for 3 weeks, the expression of mouse $6 a$-testosterone hydroxylase Cyp3a11 gene was increased in the liver. The increase by DEHP was PPARa-independent and did not match the effects of WY-14,643 in the same study.

A 2-year dietary feeding study with DEHP $(0.01$ and $0.05 \%)$ in wild type and PPARa-null mice reported that DEHP induced liver tumors independent of PPARa status [38]. Wildtype and PPARa-null mice did not exhibit equivalent levels of tumor induction. There were no statistically significant increases in liver tumors in the wild-type mice under these exposure conditions, indicating that the biological effects of exposure may have not been equivalent in these two strains. The authors reported that inflammation and oxidative stress markers were affected differently in wild type and PPARa-null mice, suggesting a possibility that different pathways were operating in two strains. The authors indicate that the increase in liver tumors could be related to the higher incidence of spontaneous liver tumors in control PPARa-null mice compared to control wild-type mice that was observed in an earlier study [116].

A follow up study [117] conducted transcript profiling to examine gene expression in the DEHP-induced tumors from the wild-type or PPARa-null mice. Microarray analysis was performed using what appeared to be only one tumor or normal untreated tissue from each strain precluding the opportunity to perform routine statistical analysis. The authors report the gene expression by RT-PCR of 5 genes involved in carcinogenesis. They compared the expression between normal untreated liver $(n=7)$ and liver tumors $(n=3)$. The liver tumors could be from both control or treated groups. They found significant increases in the 
expression of tumor versus controls in wild-type mice for Gadd45a and Apaf1 and significant increases in tumor versus controls in PPARa-null mice for Cyclin B2 and Mcl1. However, these differences are difficult to interpret because they could be due to treatment with DEHP or to differences between the tumors and surrounding tissue or both.

Eveillard et al. [105] examined whole liver gene expression in wild-type and PPARa-null C57B1/6 mice exposed to 0,20 , or $200 \mathrm{mg} / \mathrm{kg}$ DEHP for 21 days ( $n=10 /$ group). Using a nuclear receptor dedicated cDNA macroarray 284 genes with measurable expression levels were initially retained for further analysis. About one-third ( 88 genes), displayed a significant regulation in at least one of the experimental conditions (genotype or treatment effects). Fatty acid homeostasis and xenobiotic metabolism were the most represented pathways. 56 transcripts were differentially expressed between wild-type and PPARa-null control mice. DEHP (high dose) altered the expression of 49 transcripts in wild-type mice. 16 genes were altered in PPARa-null livers. Four genes were similarly altered in both strains including acyl-Co A oxidase 1 (Acox1), aldehyde dehydrogenase family 1 subfamily 1a1 (Aldh1a1), aminolevulinic acid synthase 1 (Alas1) and cytochrome P450 2c29 (Cyp2c29). Thus, most of the genes were altered by DEHP in wild-type but not PPARa-null mice.

A meta-analysis of transcript profiles of livers from rats treated with nuclear receptor activators identified PPARa and CAR as targets of DEHP [118]. This study also reported on a transcriptional analysis in wild-type mice and mice nullizygous for these two nuclear receptors. Microarray analysis showed an overlap in the profiles of DEHP, valproic acid and clofibrate treated rats with a classical activator of CAR, and to a lesser extent, an activator of PXR. The overlapping genes included $C Y P$ gene families that are often considered signature genes for nuclear receptor activation. In the same study, groups of wild-type, PPARa-null and CAR-null mice were treated with 0,200 , or $1150 \mathrm{mg} / \mathrm{kg}$ DEHP in corn oil by daily gavage for 4 days. A microarray gene expression comparison of DEHP-treated wild-type and PPARa-null mice revealed that PPARa is required for $\sim 94 \%$ of all transcriptional changes in wild-type mice. The remaining $6 \%$ of the genes were dominated by those involved in xenobiotic metabolism and are known target genes of CAR or PXR, and cholesterol biosynthesis which are regulated by several transcription factors including RXR. Cyp2b10, Cyp3a11 and Cyp3a41a, as well as Mt1 were induced by DEHP partially or completely dependent on CAR, but not PPARa as determined by comparison of effects in wild-type mice and mice nullizygous for PPARa or CAR. The expression of the CAR gene itself was increased by DEHP in PPARa-null but not in wild-type mice. Several putative CAR and PXR targets exhibited PPARa- and CAR-independent induction, including Cyp8b1, Gstm4, and Gstm7. It was concluded that DEHP requires CAR for induction of a small subset of genes (compared to PPARa) and that some liver transcriptional effects may be PPARa-independent.

Kim et al. [119] examined the effects of DEHP on nuclear receptor expression and phospholipase $\mathrm{D}$ (PLD), an enzyme that catalyses the hydrolysis of phosphatidyl choline (PC) to generate phosphatidic acid (PA) and choline. PLD is believed to play an important role in cell proliferation, survival signalling, cell transformation, and tumor progression. $\operatorname{DEHP}(500 \mathrm{mg} / \mathrm{kg} / \mathrm{d})$, was orally administered, daily to prepubertal rats (4 wks of age) for 1 , 7 , or 28 days. In this study, protein expression levels of PLD1/2, peroxisome proliferatoractivated receptor a (PPARa), and cytochrome P-450 were determined by Western blot analysis using specific antibodies. Liver weight was significantly increased in the DEHP treatment groups. A significant rise in PLD1/2 expression was observed in the livers of DEHP-exposed rats after 7 days. The authors state that PPARa, CAR, PXR, and CYP2B1 protein expression levels were markedly elevated in DEHP-treated groups. 
Several in vitro studies examined the ability of DEHP or MEHP to activate rat or mouse nuclear receptors other than PPARa. CAR trans-activation assays using mouse CAR in HepG2 cells showed that MEHP increased CAR activity greater than 3.4-fold at $100 \mu \mathrm{M}$ [120]. Effects of DEHP on rat androgen, estrogen and thyroid receptors were evaluated in reporter assays [121]. DEHP not only exhibited antiandrogenic activity $\left(\mathrm{IC}_{50}>0.1 \mathrm{mM}\right)$, but also showed androgenic activity $\left(\mathrm{EC}_{50}>0.1 \mathrm{mM}\right)$, thyroid receptor antagonist activity $\left(\mathrm{IC}_{50}>0.1 \mathrm{mM}\right)$ but not thyroid receptor agonist activity. In the estrogen receptor-mediated reporter gene assay, DEHP showed no agonist activity. The thyroid hormone disrupting potential of DEHP was studied by the effect on the thyroid hormone-dependent rat pituitary GH3 cell proliferation [94]. DEHP significantly affected the GH3 cell proliferation below levels that were cytotoxic.

Species comparisons-In Parmar et al. [122] administration of $2000 \mathrm{mg} / \mathrm{kg}$ of DEHP for a period of 7 or 15 days in rats, mice, guinea-pigs and rabbits produced a differential effect as judged by alterations in body weight gain, liver weight and activities of mixed function oxidases. DEHP exposure for 7 days caused an increase in the activity of aniline hydroxylase (CYP2E1), arylhydrocarbon hydroxylase (CYP1A) and ethylmorphine Ndemethylase (CYP3A) in rats, mice and guinea-pigs, but a decrease in that of rabbits. However, exposure for 15 days produced smaller increases in the activity of these enzymes in rats and mice and produced a decrease in the activity of these enzymes in guinea-pigs.

Hurst and Waxman [123] investigated species-specific effects of phthalates on PXR using a HepG2 cell reporter assay following transfection with mouse PXR (mPXR), human PXR (hPXR), or the hPXR allelic variants V140M, D163G, and A370T. MEHP increased the transcriptional activity of both $\mathrm{mPXR}$ and hPXR (5- and 15-fold, respectively) with $\mathrm{EC}_{50}$ values of 7-8 $\mu \mathrm{M}$. hPXR-V140M and hPXR-A370T exhibited patterns of phthalate responses similar to the wild-type receptor. By contrast, hPXR-D163G was unresponsive to all phthalate monoesters tested.

\subsection{Cell proliferation}

Human studies-No information about DEHP effects on cell proliferation in the human liver is available. Studies with cultured human hepatocytes failed to produce evidence of increased proliferation even though they were generally conducted in parallel with positive rat hepatocyte assays and at comparable doses $[92,124]$. It should be noted that only a limited number of human donors were sampled which may have affected the significance levels of these studies due to presumably higher genetic variability in the human population. In addition, the condition of the livers used for cell isolations was unknown and may also be considered as confounding variables.

Experimental systems-The effects of DEHP were evaluated in young adult male cynomolgus monkeys with emphasis on detecting hepatic and other effects seen in rats and mice after treatment with high doses of phthalates [34]. Groups of 4 monkeys received DEHP $(500 \mathrm{mg} / \mathrm{kg} / \mathrm{day})$ or vehicle $(0.5 \%$ methyl cellulose, $10 \mathrm{ml} / \mathrm{kg})$ by intragastric intubation for 14 consecutive days. DEHP had no effect on body weights or liver weights. Histopathological examination of tissues revealed no distinctive treatment-related effects in the liver, kidney, or testes. There were also no changes in any of the hepatic markers for peroxisome proliferation, including peroxisomal $\beta$-oxidation or replicative DNA synthesis. None of the test substances produced any toxicologically important changes in urinalysis, hematology, or clinical chemistry.

Rats and mice are species that are most susceptible to the induction of liver cell proliferation by DEHP. Hepatomegaly is the most pronounced early gross pathological change that 
occurs after continuous oral exposure to DEHP in rodents [70,71]. This effect is the result of both hypertrophy (increase in the size of each cell) and hyperplasia (increase in the number of cells) of liver parenchymal cells. A burst of proliferation is observed in DEHPtreated rats and mice. Elevation in the rate of mitosis of hepatocytes was observed as early as $24 \mathrm{hrs}$ after the initial dose [125], gradually increased until about 1 week of exposure, and was not sustained over longer time courses in either rats, or mice [125-127].

Cell-cycle genes appear not to be under direct transcriptional control of PPARa. Instead, several indirect mechanisms have been proposed, including involvement of miRNAs [128], activation of p38 mitogen-activated kinase [129], activation of NF- $\mathrm{kB}$ [130], or activation of Ras-like proto-oncogenes via post-translational modification [131]. None of these mechanisms has been investigated with regards to DEHP in susceptible species, and their relevance to human hazard remains to be elucidated.

DEHP and other peroxisome proliferators have not been shown to exhibit a marked effect on in vitro purified hepatocyte cultures, even in rodents. The increase in DNA synthesis, a marker of cell proliferation in rat and mouse hepatocytes in vitro has been reported to be only $120-200 \%[92,124]$. The magnitude of the induction of replicative DNA synthesis by DEHP or its metabolite MEHP is much lower than that seen in rat and mouse liver in vivo and it has been hypothesized that other cells in liver (e.g., Kupffer cells) may play an important role by potentiating the proliferative response of the hepatocytes by producing mitogenic cytokines. It is also noted that human liver may be more refractory than rodent liver to mitogenic stimuli.

Species comparisons-Male Fischer 344 rats and male Dunkin-Hartley guinea-pigs were given $950 \mathrm{mg} / \mathrm{kg} / \mathrm{day}$ DEHP by gavage for four days [84]. Significant increases in liver weight, hepatic $\beta$-oxidation activity and hepatocyte DNA replication, and decreases in hepatocyte apoptosis were observed in the rats but not the guinea-pigs.

\subsection{Apoptosis}

Suppression of apoptosis in the liver has been suggested to act as an additional mechanism through which normal balance of cell turnover may be impaired to create conditions promoting neoplastic growth [132].

Human studies-No information about DEHP effects on apoptosis in human liver is available. A report provides evidence that cultured human hepatocytes are non-responsive to anti-apoptotic effects of MEHP [124]. In this study MEHP caused no induction of $\beta$ oxidation, stimulation of DNA synthesis or suppression of apoptosis in human hepatocytes cultured from three separate donors. The lack of an effect was consistent for both spontaneous and cytokine-induced (TGF $\beta 1$, or TNFa/amanitine) apoptosis. It should be noted that human hepatocyte cultures used in these experiments may have contained up to $5 \%$ non-parenchymal cells [92]. Viability of human monocytic leukaemia U937 cells was decreased by 20 hours of exposure to $42 \mu \mathrm{g} / \mathrm{ml}$ MEHP as well as concurrent increases in DNA fragmentation [133]. Caspase-3 activity was increased by treatment with $56 \mu \mathrm{g} / \mathrm{ml}$ MEHP. This increased activity was diminished by $50 \%$ with pretreatment by selective PPAR $\gamma$ antagonists but increased 2-fold by pretreatment with a PPAR $\gamma$ ligand. A PPARa antagonist also increased MEHP-induced caspase-3 activity. The mRNA for Bcl-2, and $\mathrm{Bcl}-2 / \mathrm{Bax}$ ratios were decreased by $84 \mu \mathrm{g} / \mathrm{ml}$ MEHP with Bax mRNA increased. In human lymphoblast cells, DEHP (up to $10 \mathrm{uM}$ ) and MEHP (up to $100 \mathrm{uM}$ ) had no significant effect on the activity of caspase-3/7 after 24 hrs of exposure [134]. 
Experimental systems-In both mice and rats treated with DEHP (mice at $1150 \mathrm{mg} / \mathrm{kg}$; rats at $950 \mathrm{mg} / \mathrm{kg}$ ) by gavage for two days, suppression of apoptosis and induction of hepatocyte DNA synthesis was observed [135]. In the same study, the authors showed that MEHP was able to suppress apoptosis (both spontaneous and transforming growth factor beta1-induced) and induce hepatocyte DNA synthesis in both mouse and rat hepatocytes. Kim et al. [136] reported that DEHP exposure increased cell proliferation in MCF-7 cells but not MDA-MB-231 human breast adenocarcinoma cells at the same concentration. DEHP mimicked estrogen in the inhibition of tamoxifen-induced apoptosis in MCF-7 cells (1/3 reduction of tamoxifen-induced cell death at $3.9 \mu \mathrm{g} / \mathrm{ml}$ ). Apoptosis measured by the TUNEL assay decreased in parallel with increasing Bcl-2/Bax ratios by DEHP exposure $(3.9 \mu \mathrm{g} / \mathrm{ml})$. The survival of human cultured keratinocytes (NCDTC 2554) was decreased by DEHPinduced necrosis (not apoptosis) at $97 \mu \mathrm{g} / \mathrm{ml}$ at 4 hours exposure and $20 \mu \mathrm{g} / \mathrm{ml}$ at 24 or 48 hours of exposure [137]. Necrosis (induced by $195 \mu \mathrm{g} / \mathrm{ml}$ DEHP) was inhibited by the addition of antisense oligonucleotide against PPAR $\beta$. Western blot showed decreased pErk1, Erk2, c-myc, and increased PPAR $\beta$ at $97 \mu \mathrm{g} / \mathrm{ml}$, and increased PPARa at $20 \mu \mathrm{g} / \mathrm{ml}$ but decreased PPARa expression at $195 \mu \mathrm{g} / \mathrm{ml}$ DEHP.

\subsection{Oxidative stress}

It is widely accepted that in vivo exposure of rats or mice to DEHP leads to an increased oxidative stress in liver [138]. Induction of peroxisomal and microsomal enzymes, a pathway largely dependent on activation of PPARa, contributes to an increase in reactive oxygen species formed in the hepatocytes.

Experimental systems-Several in vivo studies have been carried out in rats in which DEHP was given and endpoints indicative of oxidative damage in the liver were measured. These include increases in lipofuscin [139-142] and malondialdehyde [143].

Takagi et al. [144, 145] investigated the relationship between hepatic peroxisome proliferation and levels of 8-hydroxydeoxyguanosine (8-OHdG) in hepatic DNA. Male Fischer 344 rats were fed $1.2 \%$ DEHP in the diet for periods of 1-12 months. Treatment with DEHP resulted in sustained stimulation of cyanide-insensitive palmitoyl-CoA activity and produced up to a two-fold increase in levels of 8-hydroxydeoxyguanosine in hepatic DNA.

A spin-trapping technique and electron spin resonance spectroscopy were used to provide direct evidence for DEHP-induced oxidative stress in liver [146]. Rats were given DEHP in the presence of the spin trapping agent a-(4-pyridyl-1-oxide)-N-tert-butylnitrone (POBN) and bile samples were collected for 4 hours of DEHP exposure. Under these conditions, the intensity of the six-line radical adduct signal increased to a maximum value of 2.5 -fold 2 hours after administration of DEHP, before peroxisomal oxidases were induced. Furthermore, DEHP given with [(13)C(2)]dimethyl sulfoxide produced a 12-line electron spin resonance spectrum, providing evidence that DEHP stimulates $(*) \mathrm{OH}$ radical formation in vivo. Furthermore, when rats were pretreated with dietary glycine, which inactivates Kupffer cells, DEHP did not increase radical signals. Moreover, similar treatments were performed in knockout mice deficient in NADPH oxidase (p47(phox) subunit). Importantly, DEHP increased oxidant production in wild-type but not in NADPH oxidase-deficient mice. These data provide evidence for the hypothesis that the molecular source of free radicals induced by peroxisome proliferators is NADPH oxidase in Kupffer cells. Radical adduct formation was not affected in PPARa-null mice. These observations provide in vivo evidence that DEHP increases free radicals in liver before peroxisomal oxidases are induced.

In a follow up study, Woods et al. [147] hypothesized that continuous treatment with peroxisome proliferators will cause a sustained formation in POBN radical adducts in liver. 
Mice were fed diets containing either WY-14,643 $(0.05 \% \mathrm{w} / \mathrm{w})$ or DEHP $(0.6 \% \mathrm{w} / \mathrm{w})$ for up to 3 weeks. Liver-derived radical production was assessed in bile samples by measuring POBN radical adducts using electron spin resonance. WY-14,643 caused a sustained increase in POBN radical adducts in mouse liver and this effect was greater than that of DEHP. Free radical production after DEHP administration occured at 2 hours and 3 weeks but not at 3 days or 1 week of exposure. To understand the molecular source of these radical species, p47phox -null and PPARa-null mice were examined after treatment with WY-14,643. No increases in radicals were observed in PPARa-null mice that were treated with WY-14,643 for 3 weeks, while the response in p47phox-nulls was similar to that of wild-type mice. These results show that PPARa, not NADPH oxidase, is critical for a sustained increase in POBN radical production caused by peroxisome proliferators in rodent liver. Therefore, peroxisome proliferator-induced POBN radical production in Kupffer cells may be limited to an acute response to these compounds in mouse liver.

In Seo et al. [143], rats were treated with DEHP $(50,200,1000 \mathrm{mg} / \mathrm{kg})$ for 14 days and the activities of metabolizing enzymes and peroxisomal enzymes were investigated. Oxidative damage was measured using 8-OHdG in the DNA and malondialdehyde (MDA) in the livers. DEHP significantly increased relative liver weights, palmitoyl-CoA oxidation and activity of carnitine acyltransferase. A dramatic and dose-dependent increase in hepatic MDA levels was observed with DEHP ( $250 \mathrm{mg} / \mathrm{kg}$ ). The $8-\mathrm{OHdG}$ in hepatic DNA was increased only in the highest DEHP exposure $(1000 \mathrm{mg} / \mathrm{kg})$ group.

Chronic treatment with DEHP or other peroxisome proliferators elicits an adaptive response to oxidative DNA damage [148], including increased DNA repair, in both rat and mouse liver [149]. The degree of induction of DNA repair gene expression correlated with the dose and carcinogenic potency of the peroxisome proliferator compounds. Furthermore, it was shown that oxidative DNA damage is a PPARa-dependent event [150].

In a chronic (22 months) dietary feeding study with DEHP in wild-type (SV/129 strain) and PPARa-null mice, treatment-related induction of oxidative DNA damage and inflammatory marker expression was observed in both strains, albeit these changes were more pronounced in PPARa-null mice exposed to DEHP [38].

Primary cultures of hepatocytes isolated from male F344 rats were incubated in medium containing MEHP and the induction of peroxisomal acyl-CoA oxidase activity and lipid peroxidation was examined [151]. The latter was determined by measuring levels of conjugated dienes in lipid fractions extracted from harvested cells. While MEHP increased the relative specific activity of peroxisomal acyl-CoA oxidase, the level of conjugated dienes was not affected by up to $200 \mu \mathrm{M}$ MEHP.

\subsection{Gap-junctional communications}

Experimental systems-The effects of DEHP or its metabolites on gap-junctional intercellular communication (GJIC) have been examined ex vivo and in vitro.

In cynomolgus monkeys, Pugh et al. [34] investigated the effects of DEHP (500 mg/kg/day), or vehicle $(0.5 \%$ methyl cellulose, $10 \mathrm{ml} / \mathrm{kg}$ ) administered by intragastric intubation for 14 consecutive days. In situ dye transfer studies, a marker for functional GJIC, using fresh liver slices revealed that DEHP had no effect on GJIC.

Isenberg et al. [152] reported inhibition of dye transfer in situ for liver strips from male B6C3F1 mice treated with DEHP (500 ppm at 2 weeks and $6000 \mathrm{ppm}$ at 4 weeks) and male F344 rats treated with DEHP (6000 ppm at 1 and 6 weeks). Food consumption was not recorded and the rats were fed ad libitum so that a $\mathrm{mg} / \mathrm{kg} /$ day dose could not be calculated. 
In a follow up study, Isenberg et al. [153] showed that dietary administration of $20000 \mathrm{mg} /$ $\mathrm{kg}$ DEHP to male rats for 2 weeks decreased intercellular communication (67\% of control) and enhanced replicative DNA synthesis (4.8-fold over control). Elevation of the relative liver weight and the induction of peroxisomal $\beta$ oxidation were also observed following treatment with $20000 \mathrm{mg} / \mathrm{kg}$ DEHP for 2 weeks. Following DEHP administration at a dose of $6000 \mathrm{mg} / \mathrm{kg}$ for 18 months, inhibition of GJIC persisted, and the relative liver weight and induction of peroxisomal $\beta$-oxidation remained elevated in both rats and male $\mathrm{B} 6 \mathrm{C} 3 \mathrm{~F} 1$ mice. In recovery studies in which DEHP was administered to male F344 rats for 2 weeks and then withdrawn, the relative liver weights, rate of peroxisomal $\beta$-oxidation, increase in replicative DNA synthesis, and inhibition of GJIC returned to control values within 2 to 4 weeks after DEHP treatment ceased. Recovery studies with phenobarbital produced similar results. MEHP was detected in the livers of animals treated with DEHP for greater than 2 weeks. However, it could not be detected after removal of DEHP from the diet for 2 weeks. This study demonstrated that inhibition of GJIC, along with indicators of peroxisomal proliferation, including increased relative liver weight and enhanced peroxisomal $\beta$ oxidation, persist while DEHP treatment continues but reverses when treatment is stopped.

Inhibition of GJIC in Chinese hamster V79 cells was reported after in vitro exposure to DEHP. The lowest effective concentration detected in these cells for inhibition of GJIC was as low as $1 \mu \mathrm{g} / \mathrm{ml}$ [154]. Inhibition of GJIC was also studied in SHE cells exposed to DEHP. Mikalsen \& Sanner [155] reported that normal SHE cells exposed to DEHP $(14 \mu \mathrm{g} / \mathrm{ml})$ for 24 hours were positive in the assay and that 5 days of exposure of DEHP $(30 \mu \mathrm{g} / \mathrm{ml})$ to transformed SHE cells gave a positive response. Cruciani et al. [156] reported transient inhibition of dye transfer in SHE cells after DEHP exposure at even lower concentrations $(<10 \mu \mathrm{g} / \mathrm{ml})$.

The only available study of MEHP for GJIC is that of Cruciani et al. [156] who reported inhibition of metabolic cooperation and inhibition of dye transfer in Chinese hamster V79 cells exposed to MEHP. The concentrations tested that inhibited metabolic cooperation (28 $\mu \mathrm{g} / \mathrm{ml}$ ) also decreased cell survival which was already at $60 \%$. Cell survival was not noted in the study of inhibition of dye transfer of MEHP but $112 \mu \mathrm{g} / \mathrm{ml}$ MEHP was reported as the dose causing this effect in V79 cells. In the same study, inhibition of dye transfer in SHE cells was reported at $7 \mu \mathrm{g} / \mathrm{ml}$ MEHP.

Species comparisons-GJIC was measured in vitro in liver cells from a variety of species 4 and $24 \mathrm{~h}$ after treatment with MEHP by lucifer yellow dye coupling [157]. GJIC was inhibited in rat and mouse hepatocytes by MEHP in a concentration-dependent manner (significantly reduced even at the lowest concentrations tested, $50 \mathrm{pM}$ ). Inhibition of GJIC in rodent cells was substantially reversed within $24 \mathrm{~h}$ of MEHP removal. In contrast, cell-tocell communication was not inhibited in hamster, cynomolgus, or human hepatocytes, or in a human liver cell line (HLEC-4 established from hepatocytes isolated from the liver of a 35-yr-old male and immortalized with a SV40 T antigen) at any concentration examined.

\section{Non-parenchymal cell-specific effects of DEHP in the liver}

\section{Experimental systems}

Rose et al. [158] tested the hypothesis that Kupffer cells are directly activated by peroxisome proliferators, including DEHP and MEHP. Kupffer cell superoxide production was measured following treatment in vitro. WY-14,643 increased superoxide production in a dose-dependent manner $(0.1$ and $50 \mu \mathrm{M})$ with half-maximal stimulation at $2.5 \mu \mathrm{M}$. DEHP and 2-ethylhexanol did not increase superoxide production even at doses 50 times higher than WY-14,643; however, MEHP activated superoxide production as effectively as WY-14,643 with half-maximal stimulation at $5 \mu \mathrm{M}$. Treatment of rats with WY-14,643 but 
not DEHP for 21 days caused a 2-fold increase in Kupffer cell superoxide production. Pretreatment of Kupffer cells in vitro with staurosporine (0.01-10 pM) completely blocked generation of superoxide, demonstrating that protein kinase $\mathrm{C}$ is required. Moreover, WY-14,643 increased Kupffer cell protein kinase C activity 3-fold. Pretreatment of Kupffer cells with the amino acid glycine $(0.01-3 \mathrm{mM})$, which blunts calcium signalling, inhibited WY-14,643-stimulated superoxide production and increased protein kinase $\mathrm{C}$ activity completely. The authors state that these data are consistent with the hypothesis that potent peroxisome proliferators (WY-14,643 and MEHP) directly activate Kupffer cell production of oxidants via mechanisms involving protein kinase C [159].

An alternative PPARa-independent mechanism for increased oxidative stress has been shown to involve activation of Kupffer cells [160]. Evidence for Kupffer cell-mediated increased oxidant production in vivo after treatment with DEHP was obtained using a spintrapping technique and electron spin resonance spectroscopy [146]. Specifically, when rats were given DEHP acutely for $2 \mathrm{hrs}$, a radical adduct signal was detected. No increase in the radical signal due to DEHP was observed when Kupffer cells were inactivated in vivo with glycine pre-treatment, or in $p 47^{p h o x}$-null mice. The rapid DEHP-induced free radical production in vivo occurred long before $\mathrm{H}_{2} \mathrm{O}_{2}$-generating enzymes in peroxisomes were induced, and it was not dependent on PPARa status.

A gene expression profiling study examined transcriptional changes induced by DEHP in mouse liver [75]. In addition to many genes that have been traditionally associated with hepatocyte-specific responses to PPs, a number of known components of the TNF/IL-1 signaling pathways, including Irak2, Myd88, I $\mathrm{kbkg}$ and others were induced very early (2 hrs) and declined at later times ( $24 \mathrm{hrs}$ ) after acute treatment with DEHP, consistent with other studies showing a time-course of Kupffer cell activation.

\section{Susceptible populations}

\subsection{Genetic polymorphisms and enzyme induction}

The human PPARa (hPPARa) is highly homologous to the rodent PPARa in overall sequence and structure [48, 61, 62], but a number of allelic variants of hPPARa have been isolated which possess properties different from the original cloned hPPARa. The L162V variant containing an amino acid change in the DNA-binding domain is found at an allelic frequency of $\sim 0.025-0.073$ in ethnically diverse populations [161-163]. In North Indians, this allele is found with high frequency $(0.745)$ [164]. The hPPARa L162V variant exhibits no response to low doses of WY but greater ligand-induced activity (up to $\sim 4$-fold) at higher doses compared to the wild-type receptor $[161,164]$. Humans carrying this variant exhibit greater decreases in total serum cholesterol to the hypolipidemic agent, bezafibrate [161]. Three different Asian populations carry a hPPARa variant (V227A) within the hinge region between the DNA binding and ligand binding domains at frequencies of 0.003-0.051 [165, 166]. This allele has been associated with decreases in serum cholesterol and triglycerides in a Japanese population [165] and in Chinese women [166]. Because of increased interactions with a co-repressor, nuclear receptor corepressor $(\mathrm{NCoR})$, this variant exhibits decreased responsiveness to PPARa activators [167].

The hPPARa-6/29 variant containing four amino acid substitutions is a dominant negative that binds to a PPRE but cannot be activated by PPARa activators [168]. The hPPARa-6/29 variant is likely very rare, as it was not detected in any of the 173 human subjects from two studies [164]. Overall, some PPARa allelic heterogeneity exists in human populations, but no variants have been identified that are more sensitive to low, environmentally-relevant doses of PPARa activators than the "wild-type" human receptor. The field would benefit 
from a side-by-side comparison of wild type and hPPARa variants in trans-activation assays to determine dose-response relationships of PPARa activators.

\subsection{Identification of groups or subpopulations with an enhanced susceptibility with a focus on fetal and neonatal responses}

A substantive database exists on the susceptibility of male reproductive system to exposures to DEHP and related chemicals during early life $[169,170]$. The overall weight of evidence for these non-cancer effects have led to public health actions in Europe and United States concerning early life exposures to DEHP-containing medical devices, toys and related consumer products [171].

Most studies conducted in rodents that examined liver effects of DEHP during gestational, lactational or post-natal exposures conclude that there is little evidence of age-specific differences in toxicity. Cimini et al. [78] treated F344 rat dams with $1 \mathrm{~g} / \mathrm{kg} /$ day of DEHP by gavage for up to 21 days from day of delivery through lactation. Pups were sacrificed on day 14 , day 21 , or day 35 following 14 days of recovery. Relative liver weights increased 1.65fold in the dams at weaning and 1.47-fold in 14- and 21-day pups. At day 21, palmitoyl-CoA oxidase increased 9.3-fold in dams, while it increased 6-fold in the nursing pups at 14 days and 4.85 -fold at 21 days. However, palmitoyl-CoA oxidase activity was substantially less in the pups than in the dams treated with DEHP (pups, $1.2 \mathrm{mU} / \mathrm{mg}$ protein at 14 days; dams, $34.4 \mathrm{mU} / \mathrm{mg}$ protein at 21 days). Dihydroxyacetone-phosphate acyltransferase (DHAP-AT) was increased about two-fold in 14- and 21-day neonates, but DHAP-AT levels were unaffected in DEHP-treated dams. Catalase activity was increased about two-fold in 14-day and 21-day neonates and adults. Following 14 days of recovery, most enzyme levels returned to normal in the dams and pups, although catalase activity remained slightly higher in both the dams and pups.

In a separate study, pregnant lactating F344 rat dams were administered by gavage $1 \mathrm{~g} / \mathrm{kg} /$ day DEHP for 21 days beginning at the day of delivery, and the nursed pups were sacrificed after two or three weeks or following a 14-day recovery period [172]. The numerical density or volume density of peroxisomes was increased marginally (less than twofold), relative to controls, in both pup groups. Dams treated for 21 days with DEHP showed a more pronounced increase in the volume density of peroxisomes (about two-fold), but the numerical density of peroxisomes was increased in the dams to the same degree as the twoor three-week pups. The increases in volume density or numerical density of peroxisomes did not decline to control levels in the three-week pups after a 14-day recovery period. Volume density of peroxisomes apparently declined to close to control levels after a recovery period of eight days in dams treated for three weeks, but there was no apparent decline in the numerical density of peroxisomes. Relative liver weights were increased about equally in two- and three-week-old neonates and adults (1.5 to 1.6-fold).

Two studies investigated the effects of DEHP on neonatal rats of different ages [76, 77]. Male Sprague-Dawley rats 6, 14, 16, 21, 42, or 86 days of age were administered (by gavage) daily doses of DEHP for five days, and 24 hours after the last dose the activities of hepatic peroxisomal enzymes, palmitoyl-CoA oxidase, and carnitine acetyltranferase were determined. The doses administered were $0,10,100,1000$, or $2000 \mathrm{mg} / \mathrm{kg} / \mathrm{day}$. Administration of $1000 \mathrm{mg} / \mathrm{kg} /$ day caused significant decreases in body weight and mortality (66\% to $70 \%$ ) in pups 14 to 18 days of age, and administration of $2000 \mathrm{mg} / \mathrm{kg} / \mathrm{day}$ caused mortality in virtually all pups of these ages. At a non-lethal dose $(100 \mathrm{mg} / \mathrm{kg} / \mathrm{day})$, absolute liver weight increases relative to those in the controls were $0 \%, 17 \%, 3 \%, 10 \%$, and $14 \%$ for 6-10-, 14-18-, 21-25-, 42-46-, and 86-89-day old pups and adults, respectively. At $100 \mathrm{mg} / \mathrm{kg} /$ day, measurements of palmitoyl-CoA activity showed that there was a greater increase only in the 14-18-day pups when compared with 86-90-day adults (6.9-fold 
increase versus a 3.98-fold increase). A greater increase in carnitine acetyl transferase was also shown at this dose level only for 14-18-day pups when compared with 86-90-day adults (7.8-fold increase versus a 4.4-fold increase). The data on increased liver weights and peroxisomal enzyme activities from this study indicate that neonatal or young adult rats differ little from adult rats in their response to treatment with DEHP, although the palmitoyl$\mathrm{CoA}$ and carnitine acetyl transferase activities were higher in the 14-18-day pups compared with adults.

A recent study in CD-1 mice investigated effects of in utero (e.g., gestational days 11-19) DEHP exposure $(100 \mathrm{mg} / \mathrm{kg} /$ day dissolved in corn oil by gavage) on liver development [173]. The data show that in utero DEHP exposure altered post-natal liver development in weanling (21 day old) mice causing significant dose-related hepatosteatosis, impaired glycogen storage, and increased beta-catenin and alpha fetal protein expression. At puberty (35 day old), a significant decrease in glycogen storage in hepatocytes was still observed in male mice. The authors concluded that DEHP alters post-natal liver development, as evidenced by the increased expression of onco-fetal genes, and delayed programming of glycogen metabolism.

In addition, several human studies have suggested that the risk of hepatoblastoma, a rare childhood cancer of the liver, is high in pre-term newborns [10-12]. While it is difficult to draw any definitive conclusions from these studies regarding the potential role of DEHP and/or PVC-containing medical devices that may have been used in neonatal care and risk of hepatoblastoma, it is well known that exposure to DEHP is high in pre-term neonates and infants [174].

\section{Toxic effects of DEHP in the lung}

\section{Human studies}

A significant increase in morbidity from both total and respiratory tract cancers was observed in a cohort of 2,031 male workers at a PVC processing plant [6]. In addition, cases of asthma and/or respiratory symptoms that may have been associated with exposure from PVC-containing plastic fumes have been reported in the literature [175]; however, in most of these studies no linkage can be made exclusively to DEHP. A number of epidemiologic studies report a high prevalence of work-related upper and lower respiratory tract symptoms among meat wrappers where the risk is substantially higher among the exposed, but the effects on lung function were reported to be inconsistent. In children, the meta-analysis [175] of 5 epidemiological studies showed an association between PVC surface materials in the home and the risk of asthma [fixed-effects model: summary odds ratio (OR), 1.55; 95\% confidence interval (CI), 1.18-2.05; four studies] and allergies [OR: 1.32; 95\% CI: 1.091.60; three studies]. A cross-sectional study found no association between phthalate exposure (urinary phthalate metabolite levels) and pulmonary function parameters among the 240 adult participants in the National Health and Nutrition Examination Survey (NHANES) participants [176].

\section{Animal studies}

There are only few rodent studies that reported adverse effects of DEHP on the lung. A 28day inhalation toxicity study of DEHP (head-nose inhalation of aerosols) in Wistar male and female rats [177] reported a statistically significant increase in relative lung weights, accompanied by increased foam-cell proliferation and thickening of the alveolar septi, at the highest exposure groups ( $230 \mathrm{mg} / \mathrm{kg} /$ day in males and $360 \mathrm{mg} / \mathrm{kg} /$ day in females). In a 104week dietary exposure study to DEHP in $\mathrm{B} 6 \mathrm{C} 3 \mathrm{~F} 1$ mice [14], an increase in mean relative lung weight in male mice at the highest dose group $(6000 \mathrm{ppm})$ was reported. A similar effect was observed in male F344 rats in a 104-week dietary feeding study at the doses of 
2500 and $12500 \mathrm{ppm}$ [15]. A study using rat tracheal strips found that mono(2-ethylhexyl) phthalate (MEHP, $0.1 \mathrm{mmol} / \mathrm{L}$ ) induced hypersensitivity to methacholine-induced contraction of rat tracheal muscle, an effect that the authors suggested may result in clinical bronchial hyperreactivity [178].

\section{Toxic effects of DEHP in the reproductive system}

\section{Human studies}

In a case-control study, occupational exposures to PVC were found to be associated with increased risk of testicular cancer [OR=6.6; 95\% confidence interval $=1.4-32]$ [5]. In humans, the database of the reproductive and developmental effects of phthalates has been growing rapidly in the past decade and numerous studies reported data suggestive of an association between exposure to DEHP and/or other phthalates and adverse effects on both male [179-183] and female [184-187] reproduction. A recent case-control study of female breast cancer study explored possible linkages to environmental exposure to phthalates [9]. Phthalate metabolites were measured in urine and an increased risk of breast cancer was identified for one of the four DEHP metabolites evaluated, mono(2-ethyl-5-carboxypentyl) phthalate. Significant negative associations were observed for monobenzyl phthalate and mono(3-carboxypropyl) phthalate. No association was found for the other DEHP metabolites: mono(2-ethylhexyl) phthalate, mono(2-ethyl-5-hydroxyhexyl) phthalate and mono(2-ethyl-5-oxohexyl) phthalate.

\section{Animal studies}

In a lifetime dietary DEHP feeding study in rats, the incidence of Leydig cell tumors was found to be increased, and was dose-related with early onset [16]. Animal evidence that DEHP is teratogenic and a reproductive toxicant has been reviewed $[68,169]$. Testicular toxicity of DEHP is independent of the status of the nuclear receptor PPARa, because identical, albeit slightly delayed, effects were observed in PPARa-null mice [36]. Effects on testicular development in rats following exposure to DEHP prenatally and during suckling or during adolescence at dose levels below those associated with peroxisome proliferation have been reported [188]. The molecular events associated with reproductive and developmental effects of DEHP and other phthalates are not well characterized, but many studies suggest that phthalate's effects on metabolism and other cellular functions leads to disruption of steroidogenesis [189], increased oxidative stress [190], increased apoptosis [191], and other events [192]. Data also suggest that both Sertoli [193] and Leydig [194] cells are targets for toxicity.

\section{Toxic effects of DEHP in the kidney}

\section{Human studies}

No data on potential toxicity or carcinogenicity of DEHP in human kidneys was identified.

\section{Animal studies}

In young adult male cynomolgus monkeys treated for 14 days with DEHP $(500 \mathrm{mg} / \mathrm{kg} / \mathrm{day})$, or vehicle $(0.5 \%$ methyl cellulose, $10 \mathrm{ml} / \mathrm{kg})$ by intragastric intubation, no distinctive treatment-related effects were observed in the kidney [34]. Several studies in mice have reported dose- and time-dependent kidney lesions following exposure to DEHP [127, 195, 196]. David et al [14] also found that DEHP is nephrotoxic and the authors suggested that because chronic progressive nephropathy is a common finding in ageing mice, DEHP may exacerbate this pathological change. The association of nephropathy with the status of PPARa was evaluated using knockout and wild-type mice [36]. Nephropathy was observed in both wild type and PPARa-null mice, albeit it was more severe in wild type animals. 
DEHP also causes nephropathy in rats [15]. It was suggested that DEHP-induced nephropathy in rodents may be related to peroxisome proliferation that has been observed in the renal proximal tubules $[78,197,198]$. While kidney tumors were not observed in chronic studies with DEHP, a related chemical, di(isononyl) phthalate was shown to cause kidney tumors in male, but not female rats [199].

\section{Toxic effects of DEHP in the immune system}

\section{Human studies}

Excess incidence of multiple myeloma among subjects exposed to phthalates and PVC at the workplace was observed in a large population-based case-control study in Denmark [8]. The possible effects of DEHP on immune function were studied in vitro. The human lung carcinoma cell line A549 was exposed to 15.6-2000 ug/ml of MEHP and concentrations of the proinflammatory cytokines IL- 6 and IL- 8 were measured in the cell culture supernatant [200]. At low (100-200 ug/ml) concentrations, a concentration-dependent increase in cytokine production was observed; however, at higher $(\sim 1000 \mathrm{ug} / \mathrm{ml})$ concentrations, the cytokine production was suppressed. When the human monocytic cell line (THP-1) or peripheral blood mono-nucleated cells obtained from allergic patients and non-allergic controls were cultured in presence of $\operatorname{MEHP}(0.2,2.0,20$, and $200 \mu \mathrm{g} / \mathrm{mL})$, no effect on cytokine production was observed [201]. A study in human peripheral blood mononuclear cells (containing 0.1-1\% basophils) showed that MEHP and DEHP (5-500 uM) had an effect on $\mathrm{IgE}$ and $\mathrm{IgG}$ release [202].

\section{Animal studies}

Several studies have been performed to assess whether various phthalates, including DEHP and MEHP, may act as sensitizers. Subcutaneous injection, not a likely route of exposure in humans yet an important mode of administration in studies of immune function, was used in several studies. MEHP was shown to have an immuno-suppressive effect, defined as a statistically significant reduction in $\mathrm{IgE}$ or IgG1 antibody production (indicative of the stimulation of the $\mathrm{T}_{\mathrm{H}} 2$ pathway, which is predominant in type I allergies) at the dose of $1000 \mathrm{ug} / \mathrm{ml}$, and an adjuvant effect, defined as a statistically significant increase in IgE or IgG1 antibody level at the dose of $10 \mathrm{ug} / \mathrm{ml}$ [203]. In a study which tested whether PPARa may be involved in the adjuvant effect of DEHP, it was shown that DEHP induced highly increased levels of ovalbumin-specific IgG1 and IgG2a, both in wild-type and in PPARanull mice, indicating that it is a mixed Th1/Th2 adjuvant and that the adjuvant mechanism is mediated through a PPARa-independent mechanism [204]. The findings that DEHP can act as an adjuvant have been challenged in a study [205] where topical administration of DEHP was without impact on antibody responses, regardless of whether it was applied locally or distant to the site of ovalbumin immunization. Inhalational exposure to MEHP (60 minutes; $0.3-43.6 \mathrm{mg} / \mathrm{m}^{3}$ ) in mice led to a concentration-dependent decrease in tidal volume and an increased number of alveolar macrophages, but no change in numbers of neutrophils, lymphocytes, eosinophils, or epithelial cells in broncho-alveolar lavage fluid [206]. An in vitro study with rabbit alveolar macrophages showed that phagocytosis, a primary function of alveolar macrophages, was significantly enhanced by DEHP (up to $2 \%$ in media) in a dose-dependent manner [207]. The effects of DEHP (50-500 uM) on antigen-induced degranulation of rat basophilic leukaemia cells (RBL-2H3) was demonstrated upon antigen stimulation [208].

\section{Conclusions}

Effects of DEHP on the liver, a primary target organ for the pleiotropic effects of DEHP and other peroxisome proliferators in rodents, have been the focus of scientific debate for the last three decades [42, 138, 209]. In the liver of rodents, parenchymal cells, also called 
hepatocytes, are a major cell type that are responsive to DEHP; however, other cells, such as resident hepatic macrophages, called Kupffer cells, may also play an important role. The increase in the number and size of peroxisomes in hepatocytes, so called 'peroxisome proliferation' that results in elevation of fatty acid metabolism, is a hallmark response to DEHP and other peroxisome proliferator compounds in the liver of susceptible species [210]. A link between peroxisome proliferation and liver tumor response has been a predominant theory to explain the cause of a hepatocarcinogenic effect, even though the experimental support is not unequivocal [211]. Other molecular events, such as induction of cell proliferation, decreased apoptosis, oxidative DNA damage, and selective clonal expansion of the initiated cells, have also been proposed to be critically involved [42].

Overall, it is believed that the events that occur relative to DEHP-induced liver carcinogenesis in rodents involve the combination of the molecular signals and multiple pathways, rather than a single hallmark event (such as activation of PPARa, peroxisome proliferation, or cell proliferation), that contribute to the formation of tumors: (i) rapid metabolism of the parental compound to primary and secondary bioactive metabolites that are readily absorbed and distributed throughout the body; (ii) receptor-independent activation of hepatic macrophages and production of oxidants; (iii) activation of PPARa in hepatocytes and sustained increases in expression of peroxisomal and non-peroxisomal metabolism-related genes; (iv) enlargement of many hepatocellular organelles (peroxisomes, mitochondria, etc.); (v) rapid, but transient increases in cell proliferation and decreases in apoptosis; (vi) sustained hepatomegaly; (vii) chronic low-level oxidative stress and accumulation of DNA damage; (viii) selective clonal expansion of initiated cells; (ix) appearance of pre-neoplastic nodules; (x) development of adenomas and carcinomas.

Despite the wide use of phthalates, including DEHP, which leads to appreciable exposures in the general population, only a limited amount of human mechanistic data is available. The majority of experimental human data comes from in vitro studies in cultured human liver cells; however, the data from these studies suggest that human cells do not give responses that parallel those observed in cultured rodent liver cells in response to DEHP or its metabolites. At the same time, even rodent liver cells do not recapitulate many events observed in the rodent liver in vivo.

Major differences in the molecular signalling events elicited by DEHP in the liver, such as the activation of the nuclear receptor peroxisome proliferator-activated receptor (PPAR) $a$, have been observed between species. In addition, it is important to note that phthalate metabolite liver concentrations in larger mammals (i.e., marmosets) are several fold lower than that of rodents in similar dose groups which suggests that differences in metabolism between small and large mammals exist and thus may further compound species comparisons [45, 138]. In 2000, an IARC review panel [212] considered DEHP and concluded that in rodents, peroxisome proliferators exercise their pleiotropic effects in liver due to activation of PPARa and that this process is essential for liver hypertrophy and hyperplasia and eventual hepatocarcinogenesis. This conclusion was based on the data from a variety of studies that considered, among many, the molecular biology of PPARa signalling in different species, transactivation potency of PPARa from different species, in vivo studies in non-human primates, and studies in genetically modified mice. It was concluded that DEHP cancer classification should be downgraded from possibly carcinogenic to humans (Group 2B) to not classifiable as to its carcinogenicity to humans (Group 3).

One of the key pieces of evidence which led to a change in DEHP cancer classification in 2000 [212] was the chronic feeding study with the potent peroxisome proliferator WY-14,643 in PPARa wild-type and -null mice that showed that the nulls were completely 
refractory to liver carcinogenesis [213]. Although this study made one of the most significant contributions to mechanistic research on peroxisome proliferators, the large dose of the agent used, shorter than 2-yr exposure, and relatively small numbers of animals evaluated, somewhat limit the broad interpretation of the findings. More recent studies that used genetically engineered mice provide important additional data key for consideration of the relevance of the PPARa mode of action to rodent and human liver carcinogenesis. These include, but are not limited to, studies in PPARa-null mice [38, 105, 117, 118], PPARa humanized transgenic mice [114], and hepatocyte-specific constitutively activated PPARa transgenic mice [111]. The data from these animal models suggest that even though activation of PPARa and the subsequent downstream events mediated by this transcription factor represent a key mechanism of action [42], it is evident that several additional molecular signals and multiple pathways in several cell types in the liver, rather than a single molecular event, contribute to the formation of liver tumors in rats and mice.

In addition, many human and rodent studies suggest that the liver is not the only target tissue for DEHP-associated carcinogenesis. Pancreas, respiratory tract, breast, testis and other tissues have been linked through either human studies of occupational, medicinal, or environmental exposure to materials that contain DEHP, or studies in rodents where exposure is known. Equally important are studies in animals and humans chronically exposed to chemicals that are thought to act via pathways similar to DEHP, such as lipid lowering drugs (e.g., fibric acid analogues), or chlorinated solvents (e.g., trichloroethylene). While there is little evidence for increased risk for liver cancer in subjects treated with fibrates, the epidemiology evidence for a causal association between exposure to trichloroethylene and liver cancer is positive but rather limited. Thus, the overall body of evidence on human cancer hazard of DEHP remains inconclusive.

Furthermore, it should be noted that even though important species differences in activation of PPARa or its signalling network by peroxisome proliferators exist, human cells express PPARa and are not devoid of trans-activation response to many peroxisome proliferators, including MEHP [55]. Important inter-individual differences in PPARa expression have been reported, suggesting that the differences in expression between species may need to be verified using a larger sample of both humans and animal strains. Thus, although quantitative differences between species may very well exist, qualitative similarities cannot be ignored, especially because DEHP and other PPARa activators are known to induce molecular responses independent of PPARa activation. It remains possible that these pathways contribute to human risk in ways somewhat different from those postulated for rat and mouse liver cancer. Overall, the mechanisms for the induction of cancer by DEHP are not entirely established and are certainly complex.

In summary, additional data from animal models and studies in humans exposed to DEHP from the environment suggest that multiple molecular signals and pathways in several cell types in the liver, rather than a single molecular event, contribute to the cancer in rats and mice. Importantly, the toxic and carcinogenic effects of DEHP are not limited to liver. The International Agency for Research on Cancer monograph 101 working group concluded [214] that the human relevance of the molecular events leading to cancer elicited by DEHP in several target tissues (e.g., liver and testis) in rats and mice can not be ruled out and DEHP was classified as possibly carcinogenic to humans (Group 2B).

\section{Acknowledgments}

The authors wish to acknowledge the members of the IARC monograph 101 meeting panel for their criticism and suggestions in developing some of the text included in this review. We also thank Drs. Barbara Abbott and Tony DeAngelo for their review of the manuscript. 


\section{References}

1. Wittassek M, Wiesmuller GA, Koch HM, Eckard R, Dobler L, Muller J, Angerer J, Schluter C. Internal phthalate exposure over the last two decades--a retrospective human biomonitoring study. Int J Hyg Environ Health. 2007; 210:319-333. [PubMed: 17400024]

2. Colacino JA, Harris TR, Schecter A. Dietary intake is associated with phthalate body burden in a nationally representative sample. Environ Health Perspect. 2010; 118:998-1003. [PubMed: 20392686]

3. Selenskas S, Teta MJ, Vitale JN. Pancreatic cancer among workers processing synthetic resins. Am J Ind Med. 1995; 28:385-398. [PubMed: 7485192]

4. Dell L, Teta MJ. Mortality among workers at a plastics manufacturing and research and development facility: 1946-1988. Am J Ind Med. 1995; 28:373-384. [PubMed: 7485191]

5. Hardell L, Ohlson CG, Fredrikson M. Occupational exposure to polyvinyl chloride as a risk factor for testicular cancer evaluated in a case-control study. Int J Cancer. 1997; 73:828-830. [PubMed: 9399660]

6. Hagmar L, Akesson B, Nielsen J, Andersson C, Linden K, Attewell R, Moller T. Mortality and cancer morbidity in workers exposed to low levels of vinyl chloride monomer at a polyvinyl chloride processing plant. Am J Ind Med. 1990; 17:553-565. [PubMed: 2337081]

7. Riboli E, Bai E, Berrino F, Merisi A. Mortality from lung cancer in an acetylene and phthalic anhydride plant. A case-referent study. Scand J Work Environ Health. 1983; 9:455-462. [PubMed: 6673103]

8. Heineman EF, Olsen JH, Pottern LM, Gomez M, Raffn E, Blair A. Occupational risk factors for multiple myeloma among Danish men. Cancer Causes Control. 1992; 3:555-568. [PubMed: 1420859]

9. Lopez-Carrillo L, Hernandez-Ramirez RU, Calafat AM, Torres-Sanchez L, Galvan-Portillo M, Needham LL, Ruiz-Ramos R, Cebrian ME. Exposure to phthalates and breast cancer risk in northern Mexico. Environ Health Perspect. 2010; 118:539-544. [PubMed: 20368132]

10. Reynolds P, Urayama KY, Von Behren J, Feusner J. Birth characteristics and hepatoblastoma risk in young children. Cancer. 2004; 100:1070-1076. [PubMed: 14983504]

11. Maruyama K, Ikeda H, Koizumi T, Tsuchida Y. Prenatal and postnatal histories of very low birthweight infants who developed hepatoblastoma. Pediatr Int. 1999; 41:82-89. [PubMed: 10200142]

12. Oue T, Kubota A, Okuyama H, Kawahara H, Nara K, Kawa K, Kitajima H. Hepatoblastoma in children of extremely low birth weight: a report from a single perinatal center. J Pediatr Surg. 2003; 38:134-137. [PubMed: 12592636]

13. Melnick RL, Morrissey RE, Tomaszewski KE. Studies by the National Toxicology Program on di(2-ethylhexyl)phthalate. Toxicol Ind Health. 1987; 3:99-118. [PubMed: 3617073]

14. David RM, Moore MR, Finney DC, Guest D. Chronic toxicity of di(2-ethylhexyl)phthalate in mice. Toxicol Sci. 2000; 58:377-385. [PubMed: 11099649]

15. David RM, Moore MR, Finney DC, Guest D. Chronic toxicity of di(2-ethylhexyl)phthalate in rats. Toxicol Sci. 2000; 55:433-443. [PubMed: 10828276]

16. Voss C, Zerban H, Bannasch P, Berger MR. Lifelong exposure to di-(2-ethylhexyl)-phthalate induces tumors in liver and testes of Sprague-Dawley rats. Toxicology. 2005; 206:359-371. [PubMed: 15588926]

17. Wilson VS, Blystone CR, Hotchkiss AK, Rider CV, Gray LE Jr. Diverse mechanisms of antiandrogen action: impact on male rat reproductive tract development. Int J Androl. 2008; 31:178187. [PubMed: 18315717]

18. Karle VA, Short BL, Martin GR, Bulas DI, Getson PR, Luban NL, O’Brien AM, Rubin RJ. Extracorporeal membrane oxygenation exposes infants to the plasticizer, di(2ethylhexyl)phthalate. Crit Care Med. 1997; 25:696-703. [PubMed: 9142038]

19. von Rettberg H, Hannman T, Subotic U, Brade J, Schaible T, Waag KL, Loff S. Use of di(2ethylhexyl)phthalate-containing infusion systems increases the risk for cholestasis. Pediatrics. 2009; 124:710-716. [PubMed: 19651587] 
20. Backes JM, Gibson CA, Ruisinger JF, Moriarty PM. Fibrates: what have we learned in the past 40 years? Pharmacotherapy. 2007; 27:412-424. [PubMed: 17316152]

21. Huttunen JK, Heinonen OP, Manninen V, Koskinen P, Hakulinen T, Teppo L, Manttari M, Frick MH. The Helsinki Heart Study: an 8.5-year safety and mortality follow-up. J Intern Med. 1994; 235:31-39. [PubMed: 8283157]

22. Frick MH, Elo O, Haapa K, Heinonen OP, Heinsalmi P, Helo P, Huttunen JK, Kaitaniemi P, Koskinen P, Manninen V. Helsinki Heart Study: primary-prevention trial with gemfibrozil in middle-aged men with dyslipidemia. Safety of treatment, changes in risk factors, and incidence of coronary heart disease. N Engl J Med. 1987; 317:1237-1245. [PubMed: 3313041]

23. WHO cooperative trial on primary prevention of ischaemic heart disease with clofibrate to lower serum cholesterol: final mortality follow-up. Report of the Committee of Principal Investigators. Lancet. 1984; 2:600-604. [PubMed: 6147641]

24. A co-operative trial in the primary prevention of ischaemic heart disease using clofibrate. Report from the Committee of Principal Investigators. Br Heart J. 1978; 40:1069-1118. [PubMed: 361054]

25. W.H.O. cooperative trial on primary prevention of ischaemic heart disease using clofibrate to lower serum cholesterol: mortality follow-up. Report of the Committee of Principal Investigators. Lancet. 1980; 2:379-385. [PubMed: 6105515]

26. Lash LH, Fisher JW, Lipscomb JC, Parker JC. Metabolism of trichloroethylene. Environ Health Perspect. 2000; 108(Suppl 2):177-200. [PubMed: 10807551]

27. Lash LH, Qian W, Putt DA, Hueni SE, Elfarra AA, Krause RJ, Parker JC. Renal and hepatic toxicity of trichloroethylene and its glutathione-derived metabolites in rats and mice: sex-, species-, and tissue-dependent differences. J Pharmacol Exp Ther. 2001; 297:155-164. [PubMed: 11259540]

28. Ramdhan DH, Komijima M, Wang D, Ito Y, Naito H, Yanagiba Y, Hayashi Y, Tanaka N, Aoyama T, Gonzalez FJ, Nakajima T. Differential response to trichloroethylene-induced hepatosteatosis in wild-type and PPARa-humanized Mice. Environ Health Perspect. 2010; 118:1557-1563. [PubMed: 20709644]

29. National Toxicology Program. Carcinogenesis Studies of Trichloroethylene (Without Epichlorohydrin) (CAS No. 79-01-6) in F344/N Rats and B6C3F1 Mice (Gavage Studies). Natl Toxicol Program Tech Rep Ser. 1990; 243:1-174. [PubMed: 12750750]

30. National Research Council. Assessing the human health risks of trichloroethylene: Key scientific issues. The National Academies Press; Washington, D.C.: 2006.

31. Scott CS, Jinot J. Trichloroethylene and Cancer: Systematic and Quantitative Review of Epidemiologic Evidence for Identifying Hazards. Int J Environ Res Public Health. 2011; 8:42384271. [PubMed: 22163205]

32. Jacobson MS, Kevy SV, Grand RJ. Effects of a plasticizer leached from polyvinyl chloride on the subhuman primate: a consequence of chronic transfusion therapy. J Lab Clin Med. 1977; 89:10661079. [PubMed: 404371]

33. Kevy SV, Jacobson MS. Hepatic effects of a phthalate ester plasticizer leached from poly(vinyl chloride) blood bags following transfusion. Environ Health Perspect. 1982; 45:57-64. [PubMed: 7140697]

34. Pugh G Jr, Isenberg JS, Kamendulis LM, Ackley DC, Clare LJ, Brown R, Lington AW, Smith JH, Klaunig JE. Effects of di-isononyl phthalate, di-2-ethylhexyl phthalate, and clofibrate in cynomolgus monkeys. Toxicol Sci. 2000; 56:181-188. [PubMed: 10869467]

35. Miura Y, Katayama H, Goto M. Studies on the metabolism of rat ascites hepatoma, with special reference of the metabolic difference between nitrogen mustard sensitive and insensitive strains. Acta Unio Int Contra Cancrum. 1959; 15(Suppl 1):199-202. [PubMed: 14423065]

36. Ward JM, Peters JM, Perella CM, Gonzalez FJ. Receptor and nonreceptor-mediated organ-specific toxicity of di(2-ethylhexyl)phthalate (DEHP) in peroxisome proliferator-activated receptor alphanull mice. Toxicol Pathol. 1998; 26:240-246. [PubMed: 9547862]

37. Nair KG, Deepadevi KV, Arun P, Kumar VM, Santhosh A, Lekshmi LR, Kurup PA. Toxic effect of systemic administration of low doses of the plasticizer di-(2-ethyl hexyl) phthalate [DEHP] in rats. Indian J Exp Biol. 1998; 36:264-272. [PubMed: 9754059] 
38. Ito Y, Yamanoshita O, Asaeda N, Tagawa Y, Lee CH, Aoyama T, Ichihara G, Furuhashi K, Kamijima M, Gonzalez FJ, Nakajima T. Di(2-ethylhexyl)phthalate induces hepatic tumorigenesis through a peroxisome proliferator-activated receptor alpha-independent pathway. J Occup Health. 2007; 49:172-182. [PubMed: 17575397]

39. Hays T, Rusyn I, Burns AM, Kennett MJ, Ward JM, Gonzalez FJ, Peters JM. Role of peroxisome proliferator-activated receptor-alpha (PPARalpha) in bezafibrate-induced hepatocarcinogenesis and cholestasis. Carcinogenesis. 2005; 26:219-227. [PubMed: 15447978]

40. National Toxicology Program. Carcinogenesis Bioassay of Di(2-ethylhexyl)phthalate (CAS No. 117-81-7) in F344 Rats and B6C3F1 Mice (Feed Studies). Natl Toxicol Program Tech Rep Ser. 1982; 217:1-127. [PubMed: 12778218]

41. David RM, Moore MR, Cifone MA, Finney DC, Guest D. Chronic peroxisome proliferation and hepatomegaly associated with the hepatocellular tumorigenesis of di(2-ethylhexyl)phthalate and the effects of recovery. Toxicol Sci. 1999; 50:195-205. [PubMed: 10478855]

42. Klaunig JE, Babich MA, Baetcke KP, Cook JC, Corton JC, David RM, Deluca JG, Lai DY, McKee RH, Peters JM, Roberts RA, Fenner-Crisp PA. PPARalpha agonist-induced rodent tumors: modes of action and human relevance. Crit Rev Toxicol. 2003; 33:655-780. [PubMed: 14727734]

43. Roberts RA. Peroxisome proliferators: mechanisms of adverse effects in rodents and molecular basis for species differences. Arch Toxicol. 1999; 73:413-418. [PubMed: 10650911]

44. Peters JM. Mechanistic evaluation of PPARa-mediated hepatocarcinogenesis: Are we there yet? Toxicol Sci. 2008; 101:1-3.

45. Guyton KZ, Chiu WA, Bateson TF, Jinot J, Scott CS, Brown RC, Caldwell JC. A reexamination of the PPAR-alpha activation mode of action as a basis for assessing human cancer risks of environmental contaminants. Environ Health Perspect. 2009; 117:1664-1672. [PubMed: 20049115]

46. Issemann I, Green S. Activation of a member of the steroid hormone receptor superfamily by peroxisome proliferators. Nature. 1990; 347:645-650. [PubMed: 2129546]

47. Dreyer C, Krey G, Keller H, Givel F, Helftenbein G, Wahli W. Control of the peroxisomal betaoxidation pathway by a novel family of nuclear hormone receptors. Cell. 1992; 68:879-887. [PubMed: 1312391]

48. Sher T, Yi HF, McBride OW, Gonzalez FJ. cDNA cloning, chromosomal mapping, and functional characterization of the human peroxisome proliferator activated receptor. Biochemistry. 1993; 32:5598-5604. [PubMed: 7684926]

49. Lapinskas PJ, Brown S, Leesnitzer LM, Blanchard S, Swanson C, Cattley RC, Corton JC. Role of PPARalpha in mediating the effects of phthalates and metabolites in the liver. Toxicology. 2005; 207:149-163. [PubMed: 15590130]

50. Maloney EK, Waxman DJ. Trans-activation of PPARalpha and PPARgamma by structurally diverse environmental chemicals. Toxicol Appl Pharmacol. 1999; 161:209-218. [PubMed: 10581215]

51. Hurst CH, Waxman DJ. Activation of PPARalpha and PPARgamma by environmental phthalate monoesters. Toxicol Sci. 2003; 74:297-308. [PubMed: 12805656]

52. Lampen A, Zimnik S, Nau H. Teratogenic phthalate esters and metabolites activate the nuclear receptors PPARs and induce differentiation of F9 cells. Toxicol Appl Pharmacol. 2003; 188:1423. [PubMed: 12668118]

53. Bility MT, Thompson JT, McKee RH, David RM, Butala JH, Vanden Heuvel JP, Peters JM. Activation of mouse and human peroxisome proliferator-zactivated receptors (PPARs) by phthalate monoesters. Toxicol Sci. 2004; 82:170-182. [PubMed: 15310864]

54. Feige JN, Gelman L, Rossi D, Zoete V, Metivier R, Tudor C, Anghel SI, Grosdidier A, Lathion C, Engelborghs Y, Michielin O, Wahli W, Desvergne B. The endocrine disruptor monoethyl-hexylphthalate is a selective peroxisome proliferator-activated receptor gamma modulator that promotes adipogenesis. J Biol Chem. 2007; 282:19152-19166. [PubMed: 17468099]

55. Rotroff DM, Beam AL, Dix DJ, Farmer A, Freeman KM, Houck KA, Judson RS, LeCluyse EL, Martin MT, Reif DM, Ferguson SS. Xenobiotic-metabolizing enzyme and transporter gene expression in primary cultures of human hepatocytes modulated by ToxCast chemicals. J Toxicol Environ Health B Crit Rev. 2010; 13:329-346. [PubMed: 20574906] 
56. Martin MT, Dix DJ, Judson RS, Kavlock RJ, Reif DM, Richard AM, Rotroff DM, Romanov S, Medvedev A, Poltoratskaya N, Gambarian M, Moeser M, Makarov SS, Houck KA. Impact of environmental chemicals on key transcription regulators and correlation to toxicity end points within EPA's ToxCast program. Chem Res Toxicol. 2010; 23:578-590. [PubMed: 20143881]

57. Ito Y, Yamanoshita O, Kurata Y, Kamijima M, Aoyama T, Nakajima T. Induction of peroxisome proliferator-activated receptor alpha (PPARalpha)-related enzymes by di(2-ethylhexyl) phthalate (DEHP) treatment in mice and rats, but not marmosets. Arch Toxicol. 2007; 81:219-226. [PubMed: 16937134]

58. Palmer CN, Hsu MH, Griffin KJ, Raucy JL, Johnson EF. Peroxisome proliferator activated receptor-alpha expression in human liver. Mol Pharmacol. 1998; 53:14-22. [PubMed: 9443928]

59. Walgren JE, Kurtz DT, McMillan JM. Expression of PPAR(alpha) in human hepatocytes and activation by trichloroacetate and dichloroacetate. Res Commun Mol Pathol Pharmacol. 2000; 108:116-132. [PubMed: 11758968]

60. Choudhury AI, Sims HM, Horley NJ, Roberts RA, Tomlinson SR, Salter AM, Bruce M, Shaw PN, Kendall D, Barrett DA, Bell DR. Molecular analysis of peroxisome proliferation in the hamster. Toxicol Appl Pharmacol. 2004; 197:9-18. [PubMed: 15126070]

61. Mukherjee R, Jow L, Noonan D, McDonnell DP. Human and rat peroxisome proliferator activated receptors (PPARs) demonstrate similar tissue distribution but different responsiveness to PPAR activators. J Steroid Biochem Mol Biol. 1994; 51:157-166. [PubMed: 7981125]

62. Tugwood JD, Aldridge TC, Lambe KG, Macdonald N, Woodyatt NJ. Peroxisome proliferatoractivated receptors: structures and function. Ann N Y Acad Sci. 1996; 804:252-265. [PubMed: 8993548]

63. Gervois P, Torra IP, Chinetti G, Grotzinger T, Dubois G, Fruchart JC, Fruchart-Najib J, Leitersdorf E, Staels B. A truncated human peroxisome proliferator-activated receptor alpha splice variant with dominant negative activity. Mol Endocrinol. 1999; 13:1535-1549. [PubMed: 10478844]

64. Hanselman JC, Vartanian MA, Koester BP, Gray SA, Essenburg AD, Rea TJ, Bisgaier CL, Pape ME. Expression of the mRNA encoding truncated PPAR alpha does not correlate with hepatic insensitivity to peroxisome proliferators. Mol Cell Biochem. 2001; 217:91-97. [PubMed: 11269670]

65. Rosen MB, Abbott BD, Wolf DC, Corton JC, Wood CR, Schmid JE, Das KP, Zehr RD, Blair ET, Lau C. Gene profiling in the livers of wild-type and PPARalpha-null mice exposed to perfluorooctanoic acid. Toxicol Pathol. 2008; 36:592-607. [PubMed: 18467677]

66. Ganning AE, Brunk U, Dallner G. Phthalate esters and their effect on the liver. Hepatology. 1984; 4:541-547. [PubMed: 6373551]

67. Ganning AE, Brunk U, Edlund C, Elhammer A, Dallner G. Effects of prolonged administration of phthalate ester on the liver. Environ Health Perspect. 1987; 73:251-258. [PubMed: 3665868]

68. Huber WW, Grasl-Kraupp B, Schulte-Hermann R. Hepatocarcinogenic potential of di(2ethylhexyl)phthalate in rodents and its implications on human risk. Crit Rev Toxicol. 1996; 26:365-481. [PubMed: 8817083]

69. Tomonari Y, Kurata Y, David RM, Gans G, Kawasuso T, Katoh M. Effect of di(2-ethylhexyl) phthalate (DEHP) on genital organs from juvenile common marmosets: I. Morphological and biochemical investigation in 65-week toxicity study. J Toxicol Environ Health A. 2006; 69:16511672. [PubMed: 16854791]

70. Lake BG, Gangolli SD, Grasso P, Lloyd AG. Studies on the hepatic effects of orally administered di-(2-ethylhexyl) phthalate in the rat. Toxicol Appl Pharmacol. 1975; 32:355-367. [PubMed: 168667]

71. Reddy JK, Moody DE, Azarnoff DL, Rao MS. Di-(2-ethylhexyl)phthalate: an industrial plasticizer induces hypolipidemia and enhances hepatic catalase and carnitine acetyltransferase activities in rat and mice. Life Sci. 1976; 18:941-945. [PubMed: 1271963]

72. Reddy JK, Goel SK, Nemali MR, Carrino JJ, Laffler TG, Reddy MK, Sperbeck SJ, Osumi T, Hashimoto T, Lalwani ND. Transcription regulation of peroxisomal fatty acyl-CoA oxidase and enoyl-CoA hydratase/3-hydroxyacyl-CoA dehydrogenase in rat liver by peroxisome proliferators. Proc Natl Acad Sci U S A. 1986; 83:1747-1751. [PubMed: 3456610] 
73. Yamazaki T, Hirose A, Sakamoto T, Okazaki M, Mitsumoto A, Kudo N, Kawashima Y. Peroxisome proliferators attenuate free arachidonic acid pool in the kidney through inducing lysophospholipid acyltransferases. J Pharmacol Sci. 2009; 111:201-210. [PubMed: 19809218]

74. Wong JS, Gill SS. Gene expression changes induced in mouse liver by di(2-ethylhexyl) phthalate. Toxicol Appl Pharmacol. 2002; 185:180-196. [PubMed: 12498735]

75. Currie RA, Bombail V, Oliver JD, Moore DJ, Lim FL, Gwilliam V, Kimber I, Chipman K, Moggs JG, Orphanides G. Gene ontology mapping as an unbiased method for identifying molecular pathways and processes affected by toxicant exposure: application to acute effects caused by the rodent non-genotoxic carcinogen diethylhexylphthalate. Toxicol Sci. 2005; 86:453-469. [PubMed: 15901911]

76. Dostal LA, Jenkins WL, Schwetz BA. Hepatic peroxisome proliferation and hypolipidemic effects of di(2-ethylhexyl)phthalate in neonatal and adult rats. Toxicol Appl Pharmacol. 1987; 87:81-90. [PubMed: 3798454]

77. Dostal LA, Weaver RP, Schwetz BA. Transfer of di(2-ethylhexyl) phthalate through rat milk and effects on milk composition and the mammary gland. Toxicol Appl Pharmacol. 1987; 91:315-325. [PubMed: 2892284]

78. Cimini AM, Sulli A, Stefanini S, Serafini B, Moreno S, Rossi L, Giorgi M, Ceru MP. Effects of di(2-ethylhexyl)phthalate on peroxisomes of liver, kidney and brain of lactating rats and their pups. Cell Mol Biol (Noisy -le-grand). 1994; 40:1063-1076. [PubMed: 7873979]

79. Kurata Y, Kidachi F, Yokoyama M, Toyota N, Tsuchitani M, Katoh M. Subchronic toxicity of Di(2-ethylhexyl)phthalate in common marmosets: lack of hepatic peroxisome proliferation, testicular atrophy, or pancreatic acinar cell hyperplasia. Toxicol Sci. 1998; 42:49-56. [PubMed: 9538047]

80. Gray TJ, Beamand JA, Lake BG, Foster JR, Gangolli SD. Peroxisome proliferation in cultured rat hepatocytes produced by clofibrate and phthalate ester metabolites. Toxicol Lett. 1982; 10:273279. [PubMed: 7080097]

81. Gray TJ, Lake BG, Beamand JA, Foster JR, Gangolli SD. Peroxisome proliferation in primary cultures of rat hepatocytes. Toxicol Appl Pharmacol. 1983; 67:15-25. [PubMed: 6845354]

82. Grolier P, Elcombe CR. In vitro inhibition of carnitine acyltransferase activity in mitochondria from rat and mouse liver by a diethylhexylphthalate metabolite. Biochem Pharmacol. 1993; 45:827-832. [PubMed: 8452557]

83. Osumi T, Hashimoto T. Enhancement of fatty acyl-CoA oxidizing activity in rat liver peroxisomes by di-(i-ethylhexyl)phthalate. J Biochem. 1978; 83:1361-1365. [PubMed: 659402]

84. Hasmall SC, James NH, Macdonald N, Soames AR, Roberts RA. Species differences in response to diethylhexylphthalate: suppression of apoptosis, induction of DNA synthesis and peroxisome proliferator activated receptor alpha-mediated gene expression. Arch Toxicol. 2000; 74:85-91. [PubMed: 10839475]

85. Lake BG, Gray TJ, Foster JR, Stubberfield CR, Gangolli SD. Comparative studies on di-(2ethylhexyl) phthalate-induced hepatic peroxisome proliferation in the rat and hamster. Toxicol Appl Pharmacol. 1984; 72:46-60. [PubMed: 6710484]

86. Rhodes C, Orton TC, Pratt IS, Batten PL, Bratt H, Jackson SJ, Elcombe CR. Comparative pharmacokinetics and subacute toxicity of di(2-ethylhexyl) phthalate (DEHP) in rats and marmosets: extrapolation of effects in rodents to man. Environ Health Perspect. 1986; 65:299 307. [PubMed: 3086078]

87. Short RD, Robinson EC, Lington AW, Chin AE. Metabolic and peroxisome proliferation studies with di(2-ethylhexyl)phthalate in rats and monkeys. Toxicol Ind Health. 1987; 3:185-195. [PubMed: 3617067]

88. Mitchell FE, Price SC, Hinton RH, Grasso P, Bridges JW. Time and dose-response study of the effects on rats of the plasticizer di(2-ethylhexyl) phthalate. Toxicol Appl Pharmacol. 1985; 81:371-392. [PubMed: 2867621]

89. Lake BG, Gray TJ, Gangolli SD. Hepatic effects of phthalate esters and related compounds--in vivo and in vitro correlations. Environ Health Perspect. 1986; 67:283-290. [PubMed: 3757955]

90. Dirven HA, van den Broek PH, Peeters MC, Peters JG, Mennes WC, Blaauboer BJ, Noordhoek J, Jongeneelen FJ. Effects of the peroxisome proliferator mono(2-ethylhexyl)phthalate in primary 
hepatocyte cultures derived from rat, guinea pig, rabbit, and monkey. Biochem Pharmacol. 1993; 45:2425-2434. [PubMed: 8328980]

91. Cornu MC, Lhuguenot JC, Brady AM, Moore R, Elcombe CR. Identification of the proximate peroxisome proliferator(s) derived from di(2-ethylhexyl)adipate and species differences in response. Biochem Pharmacol. 1992; 43:2129-2134. [PubMed: 1599500]

92. Goll V, Alexandre E, Viollon-Abadie C, Nicod L, Jaeck D, Richert L. Comparison of the effects of various peroxisome proliferators on peroxisomal enzyme activities, DNA synthesis, and apoptosis in rat and human hepatocyte cultures. Toxicol Appl Pharmacol. 1999; 160:21-32. [PubMed: 10502499]

93. Zacharewski TR, Meek MD, Clemons JH, Wu ZF, Fielden MR, Matthews JB. Examination of the in vitro and in vivo estrogenic activities of eight commercial phthalate esters. Toxicol Sci. 1998; 46:282-293. [PubMed: 10048131]

94. Ghisari M, Bonefeld-Jorgensen EC. Effects of plasticizers and their mixtures on estrogen receptor and thyroid hormone functions. Toxicol Lett. 2009; 189:67-77. [PubMed: 19463926]

95. Takeuchi S, Iida M, Kobayashi S, Jin K, Matsuda T, Kojima H. Differential effects of phthalate esters on transcriptional activities via human estrogen receptors alpha and beta, and androgen receptor. Toxicology. 2005; 210:223-233. [PubMed: 15840436]

96. Kang SC, Lee BM. DNA methylation of estrogen receptor alpha gene by phthalates. J Toxicol Environ Health A. 2005; 68:1995-2003. [PubMed: 16326419]

97. Parks LG, Ostby JS, Lambright CR, Abbott BD, Klinefelter GR, Barlow NJ, Gray LE Jr. The plasticizer diethylhexyl phthalate induces malformations by decreasing fetal testosterone synthesis during sexual differentiation in the male rat. Toxicol Sci. 2000; 58:339-349. [PubMed: 11099646]

98. Kruger T, Long M, Bonefeld-Jorgensen EC. Plastic components affect the activation of the aryl hydrocarbon and the androgen receptor. Toxicology. 2008; 246:112-123. [PubMed: 18294747]

99. Takeshita A, Koibuchi N, Oka J, Taguchi M, Shishiba Y, Ozawa Y. Bisphenol-A, an environmental estrogen, activates the human orphan nuclear receptor, steroid and xenobiotic receptor-mediated transcription. Eur J Endocrinol. 2001; 145:513-517. [PubMed: 11581012]

100. Takeshita A, Inagaki K, Igarashi-Migitaka J, Ozawa Y, Koibuchi N. The endocrine disrupting chemical, diethylhexyl phthalate, activates MDR1 gene expression in human colon cancer LS174T cells. J Endocrinol. 2006; 190:897-902. [PubMed: 17003290]

101. Cooper BW, Cho TM, Thompson PM, Wallace AD. Phthalate induction of CYP3A4 is dependent on glucocorticoid regulation of PXR expression. Toxicol Sci. 2008; 103:268-277. [PubMed: 18332045]

102. Mnif W, Pascussi JM, Pillon A, Escande A, Bartegi A, Nicolas JC, Cavailles V, Duchesne MJ, Balaguer P. Estrogens and antiestrogens activate hPXR. Toxicol Lett. 2007; 170:19-29. [PubMed: 17379461]

103. Auerbach SS, Dekeyser JG, Stoner MA, Omiecinski CJ. CAR2 displays unique ligand binding and RXRalpha heterodimerization characteristics. Drug Metab Dispos. 2007; 35:428-439. [PubMed: 17194715]

104. Dekeyser JG, Stagliano MC, Auerbach SS, Prabhu KS, Jones AD, Omiecinski CJ. Di(2ethylhexyl) phthalate is a highly potent agonist for the human constitutive androstane receptor splice variant CAR2. Mol Pharmacol. 2009; 75:1005-1013. [PubMed: 19211671]

105. Eveillard A, Mselli-Lakhal L, Mogha A, Lasserre F, Polizzi A, Pascussi JM, Guillou H, Martin PG, Pineau T. Di-(2-ethylhexyl)-phthalate (DEHP) activates the constitutive androstane receptor (CAR): a novel signalling pathway sensitive to phthalates. Biochem Pharmacol. 2009; 77:17351746. [PubMed: 19428328]

106. Dekeyser JG, Laurenzana EM, Peterson EC, Chen T, Omiecinski CJ. Selective phthalate activation of naturally occurring human constitutive androstane receptor splice variants and the pregnane $\times$ receptor. Toxicol Sci. 2011; 120:381-391. [PubMed: 21227907]

107. Seree E, Villard PH, Pascussi JM, Pineau T, Maurel P, Nguyen QB, Fallone F, Martin PM, Champion S, Lacarelle B, Savouret JF, Barra Y. Evidence for a new human CYP1A1 regulation pathway involving PPAR-alpha and 2 PPRE sites. Gastroenterology. 2004; 127:1436-1445. [PubMed: 15521013] 
108. Voskoboinik I, Ooi SG, Drew R, Ahokas JT. Peroxisome proliferators increase the formation of BPDE-DNA adducts in isolated rat hepatocytes. Toxicology. 1997; 122:81-91. [PubMed: 9274804]

109. Shaban Z, El Shazly S, Ishizuka M, Kimura K, Kazusaka A, Fujita S. PPARalpha-dependent modulation of hepatic CYP1A by clofibric acid in rats. Arch Toxicol. 2004; 78:496-507. [PubMed: 15127182]

110. Eagon PK, Chandar N, Epley MJ, Elm MS, Brady EP, Rao KN. Di(2-ethylhexyl)phthalateinduced changes in liver estrogen metabolism and hyperplasia. Int J Cancer. 1994; 58:736-743. [PubMed: 7915705]

111. Yang Q, Ito S, Gonzalez FJ. Hepatocyte-restricted constitutive activation of PPAR alpha induces hepatoproliferation but not hepatocarcinogenesis. Carcinogenesis. 2007; 28:1171-1177. [PubMed: 17331954]

112. Weglarz TC, Sandgren EP. Cell cross-talk mediates PPARalpha null hepatocyte proliferation after peroxisome proliferator exposure. Carcinogenesis. 2004; 25:107-112. [PubMed: 14514660]

113. Cheung C, Akiyama TE, Ward JM, Nicol CJ, Feigenbaum L, Vinson C, Gonzalez FJ. Diminished hepatocellular proliferation in mice humanized for the nuclear receptor peroxisome proliferatoractivated receptor alpha. Cancer Res. 2004; 64:3849-3854. [PubMed: 15172993]

114. Morimura K, Cheung C, Ward JM, Reddy JK, Gonzalez FJ. Differential susceptibility of mice humanized for peroxisome proliferator-activated receptor \{alpha\} to Wy-14,643-induced liver tumorigenesis. Carcinogenesis. 2006

115. Fan LQ, You L, Brown-Borg H, Brown S, Edwards RJ, Corton JC. Regulation of phase I and phase II steroid metabolism enzymes by PPAR alpha activators. Toxicology. 2004; 204:109-121. [PubMed: 15388238]

116. Howroyd P, Swanson C, Dunn C, Cattley RC, Corton JC. Decreased longevity and enhancement of age-dependent lesions in mice lacking the nuclear receptor peroxisome proliferator-activated receptor alpha (PPARalpha). Toxicol Pathol. 2004; 32:591-599. [PubMed: 15603543]

117. Takashima K, Ito Y, Gonzalez FJ, Nakajima T. Different mechanisms of DEHP-induced hepatocellular adenoma tumorigenesis in wild-type and Ppar alpha-null mice. J Occup Health. 2008; 50:169-180. [PubMed: 18403868]

118. Ren H, Aleksunes LM, Wood C, Vallanat B, George MH, Klaassen CD, Corton JC. Characterization of peroxisome proliferator-activated receptor alpha--independent effects of PPARalpha activators in the rodent liver: di-(2-ethylhexyl) phthalate also activates the constitutive-activated receptor. Toxicol Sci. 2010; 113:45-59. [PubMed: 19850644]

119. Kim NY, Kim TH, Lee E, Patra N, Lee J, Shin MO, Kwack SJ, Park KL, Han SY, Kang TS, Kim SH, Lee BM, Kim HS. Functional role of phospholipase D (PLD) in di(2-ethylhexyl) phthalateinduced hepatotoxicity in Sprague-Dawley rats. J Toxicol Environ Health A. 2010; 73:15601569. [PubMed: 20954081]

120. Baldwin WS, Roling JA. A concentration addition model for the activation of the constitutive androstane receptor by xenobiotic mixtures. Toxicol Sci. 2009; 107:93-105. [PubMed: 18832183]

121. Shen O, Du G, Sun H, Wu W, Jiang Y, Song L, Wang X. Comparison of in vitro hormone activities of selected phthalates using reporter gene assays. Toxicol Lett. 2009; 191:9-14. [PubMed: 19643168]

122. Parmar D, Srivastava SP, Seth PK. Effect of di(2-ethylhexyl)phthalate (DEHP) on hepatic mixed function oxidases in different animal species. Toxicol Lett. 1988; 40:209-217. [PubMed: 3354005]

123. Hurst CH, Waxman DJ. Environmental phthalate monoesters activate pregnane $\mathrm{X}$ receptormediated transcription. Toxicol Appl Pharmacol. 2004; 199:266-274. [PubMed: 15364542]

124. Hasmall SC, James NH, Macdonald N, West D, Chevalier S, Cosulich SC, Roberts RA. Suppression of apoptosis and induction of DNA synthesis in vitro by the phthalate plasticizers monoethylhexylphthalate (MEHP) and diisononylphthalate (DINP): a comparison of rat and human hepatocytes in vitro. Arch Toxicol. 1999; 73:451-456. [PubMed: 10650916] 
125. Smith-Oliver T, Butterworth BE. Correlation of the carcinogenic potential of di(2ethylhexyl)phthalate (DEHP) with induced hyperplasia rather than with genotoxic activity. Mutat Res. 1987; 188:21-28. [PubMed: 3574334]

126. Marsman DS, Cattley RC, Conway JG, Popp JA. Relationship of hepatic peroxisome proliferation and replicative DNA synthesis to the hepatocarcinogenicity of the peroxisome proliferators di(2ethylhexyl)phthalate and [4-chloro-6-(2,3-xylidino)-2- pyrimidinylthio]acetic acid (Wy-14,643) in rats. Cancer Res. 1988; 48:6739-6744. [PubMed: 3180084]

127. Ward JM, Hagiwara A, Anderson LM, Lindsey K, Diwan BA. The chronic hepatic or renal toxicity of di(2-ethylhexyl) phthalate, acetaminophen, sodium barbital, and phenobarbital in male B6C3F1 mice: autoradiographic, immunohistochemical, and biochemical evidence for levels of DNA synthesis not associated with carcinogenesis or tumor promotion. Toxicol Appl Pharmacol. 1988; 96:494-506. [PubMed: 3206528]

128. Shah YM, Morimura K, Yang Q, Tanabe T, Takagi M, Gonzalez FJ. Peroxisome proliferatoractivated receptor alpha regulates a microRNA-mediated signaling cascade responsible for hepatocellular proliferation. Mol Cell Biol. 2007; 27:4238-4247. [PubMed: 17438130]

129. Roberts RA, James NH, Cosulich SC. The role of protein kinase B and mitogen-activated protein kinase in epidermal growth factor and tumor necrosis factor alpha-mediated rat hepatocyte survival and apoptosis. Hepatology. 2000; 31:420-427. [PubMed: 10655266]

130. Rusyn I, Yamashina S, Segal BH, Schoonhoven R, Holland SM, Cattley RC, Swenberg JA, Thurman RG. Oxidants from nicotinamide adenine dinucleotide phosphate oxidase are involved in triggering cell proliferation in the liver due to peroxisome proliferators. Cancer Res. 2000; 60:4798-4803. [PubMed: 10987289]

131. Wheeler MD, Smutney OM, Check JF, Rusyn I, Schulte-Hermann R, Thurman RG. Impaired Ras membrane association and activation in PPARalpha knockout mice after partial hepatectomy. Am J Physiol Gastrointest Liver Physiol. 2003; 284:G302-G312. [PubMed: 12388208]

132. Roberts RA, Ganey PE, Ju C, Kamendulis LM, Rusyn I, Klaunig JE. Role of the Kupffer cell in mediating hepatic toxicity and carcinogenesis. Toxicol Sci. 2007; 96:2-15. [PubMed: 17122412]

133. Yokoyama Y, Okubo T, Kano I, Sato S, Kano K. Induction of apoptosis by mono(2ethylhexyl)phthalate (MEHP) in U937 cells. Toxicol Lett. 2003; 144:371-381. [PubMed: 12927354]

134. O'Shea SH, Schwarz J, Kosyk O, Ross PK, Ha MJ, Wright FA, Rusyn I. In vitro screening for population variability in chemical toxicity. Toxicol Sci. 2011; 119:398-407. [PubMed: 20952501]

135. James NH, Soames AR, Roberts RA. Suppression of hepatocyte apoptosis and induction of DNA synthesis by the rat and mouse hepatocarcinogen diethylhexylphlathate (DEHP) and the mouse hepatocarcinogen 1,4-dichlorobenzene (DCB). Arch Toxicol. 1998; 72:784-790. [PubMed: 9950075]

136. Kim IY, Han SY, Moon A. Phthalates inhibit tamoxifen-induced apoptosis in MCF-7 human breast cancer cells. J Toxicol Environ Health A. 2004; 67:2025-2035. [PubMed: 15513900]

137. Martinasso G, Maggiora M, Trombetta A, Canuto RA, Muzio G. Effects of di(2-ethylhexyl) phthalate, a widely used peroxisome proliferator and plasticizer, on cell growth in the human keratinocyte cell line NCTC 2544. J Toxicol Environ Health A. 2006; 69:353-365. [PubMed: 16455614]

138. Rusyn I, Peters JM, Cunningham ML. Modes of action and species-specific effects of di-(2ethylhexyl)phthalate in the liver. Crit Rev Toxicol. 2006; 36:459-479. [PubMed: 16954067]

139. Lake BG, Kozlen SL, Evans JG, Gray TJ, Young PJ, Gangolli SD. Effect of prolonged administration of clofibric acid and di-(2- ethylhexyl)phthalate on hepatic enzyme activities and lipid peroxidation in the rat. Toxicology. 1987; 44:213-228. [PubMed: 3564055]

140. Cattley RC, Conway JG, Popp JA. Association of persistent peroxisome proliferation and oxidative injury with hepatocarcinogenicity in female F-344 rats fed di(2-ethylhexyl)phthalate for 2 years. Cancer Lett. 1987; 38:15-22. [PubMed: 3690505]

141. Hinton RH, Mitchell FE, Mann A, Chescoe D, Price SC, Nunn A, Grasso P, Bridges JW. Effects of phthalic acid esters on the liver and thyroid. Environ Health Perspect. 1986; 70:195-210. [PubMed: 3830106] 
142. Conway JG, Tomaszewski KE, Olson MJ, Cattley RC, Marsman DS, Popp JA. Relationship of oxidative damage to the hepatocarcinogenicity of the peroxisome proliferators di(2ethylhexyl)phthalate and Wy-14,643. Carcinogenesis. 1989; 10:513-519. [PubMed: 2924396]

143. Seo KW, Kim KB, Kim YJ, Choi JY, Lee KT, Choi KS. Comparison of oxidative stress and changes of xenobiotic metabolizing enzymes induced by phthalates in rats. Food Chem Toxicol. 2004; 42:107-114. [PubMed: 14630134]

144. Takagi A, Sai K, Umemura T, Hasegawa R, Kurokawa Y. Significant increase of 8 hydroxydeoxyguanosine in liver DNA of rats following short-term exposure to the peroxisome proliferators di(2- ethylhexyl)phthalate and di(2-ethylhexyl)adipate. Jpn J Cancer Res. 1990; 81:213-215. [PubMed: 2112523]

145. Takagi A, Sai K, Umemura T, Hasegawa R, Kurokawa Y. Relationship between hepatic peroxisome proliferation and 8-hydroxydeoxyguanosine formation in liver DNA of rats following long-term exposure to three peroxisome proliferators; di(2-ethylhexyl) phthalate, aluminium clofibrate and simfibrate. Cancer Lett. 1990; 53:33-38. [PubMed: 2397479]

146. Rusyn I, Kadiiska MB, Dikalova A, Kono H, Yin M, Tsuchiya K, Mason RP, Peters JM, Gonzalez FJ, Segal BH, Holland SM, Thurman RG. Phthalates rapidly increase production of reactive oxygen species in vivo: role of Kupffer cells. Mol Pharmacol. 2001; 59:744-750. [PubMed: 11259618]

147. Woods CG, Burns AM, Maki A, Bradford BU, Cunningham ML, Connor HD, Kadiiska MB, Mason RP, Peters JM, Rusyn I. Sustained formation of alpha-(4-pyridyl-1-oxide)-N-tertbutylnitrone radical adducts in mouse liver by peroxisome proliferators is dependent upon peroxisome proliferator-activated receptor-alpha, but not NADPH oxidase. Free Radic Biol Med. 2007; 42:335-342. [PubMed: 17210446]

148. Powell CL, Swenberg JA, Rusyn I. Expression of base excision DNA repair genes as a biomarker of oxidative DNA damage. Cancer Lett. 2005; 229:1-11. [PubMed: 16157213]

149. Rusyn I, Denissenko MF, Wong VA, Butterworth BE, Cunningham ML, Upton PB, Thurman RG, Swenberg JA. Expression of base excision repair enzymes in rat and mouse liver is induced by peroxisome proliferators and is dependent upon carcinogenic potency. Carcinogenesis. 2000; 21:2141-2145. [PubMed: 11133801]

150. Rusyn I, Asakura S, Pachkowski B, Bradford BU, Denissenko MF, Peters JM, Holland SM, Reddy JK, Cunningham ML, Swenberg JA. Expression of base excision DNA repair genes is a sensitive biomarker for in vivo detection of chemical-induced chronic oxidative stress: Identification of the molecular source of radicals responsible for DNA damage by peroxisome proliferators. Cancer Res. 2004; 64:1050-1057. [PubMed: 14871837]

151. Tomaszewski KE, Heindel SW, Jenkins WL, Melnick RL. Induction of peroxisomal acyl CoA oxidase activity and lipid peroxidation in primary rat hepatocyte cultures. Toxicology. 1990; 65:49-60. [PubMed: 2274969]

152. Isenberg JS, Kamendulis LM, Smith JH, Ackley DC, Pugh G Jr, Lington AW, Klaunig JE. Effects of Di-2-ethylhexyl phthalate (DEHP) on gap-junctional intercellular communication (GJIC), DNA synthesis, and peroxisomal beta oxidation (PBOX) in rat, mouse, and hamster liver. Toxicol Sci. 2000; 56:73-85. [PubMed: 10869455]

153. Isenberg JS, Kamendulis LM, Ackley DC, Smith JH, Pugh G Jr, Lington AW, McKee RH, Klaunig JE. Reversibility and persistence of di-2-ethylhexyl phthalate (DEHP)- and phenobarbital-induced hepatocellular changes in rodents. Toxicol Sci. 2001; 64:192-199. [PubMed: 11719701]

154. Malcolm AR, Mills LJ. Inhibition of gap-junctional intercellular communication between Chinese hamster lung fibroblasts by di(2-ethylhexyl) phthalate (DEHP) and trisodium nitrilotriacetate monohydrate (NTA). Cell Biol Toxicol. 1989; 5:145-153. [PubMed: 2766028]

155. Mikalsen SO, Sanner T. Intercellular communication in colonies of Syrian hamster embryo cells and the susceptibility for morphological transformation. Carcinogenesis. 1993; 14:251-257. [PubMed: 8435866]

156. Cruciani V, Mikalsen SO, Vasseur P, Sanner T. Effects of peroxisome proliferators and 12-Otetradecanoyl phorbol-13-acetate on intercellular communication and connexin 43 in two hamster fibroblast systems. Int J Cancer. 1997; 73:240-248. [PubMed: 9335450] 
157. Kamendulis LM, Isenberg JS, Smith JH, Pugh G Jr, Lington AW, Klaunig JE. Comparative effects of phthalate monoesters on gap junctional intercellular communication and peroxisome proliferation in rodent and primate hepatocytes. J Toxicol Environ Health A. 2002; 65:569-588. [PubMed: 11995694]

158. Rose ML, Rivera CA, Bradford BU, Graves LM, Cattley RC, Schoonhoven R, Swenberg JA, Thurman RG. Kupffer cell oxidant production is central to the mechanism of peroxisome proliferators. Carcinogenesis. 1999; 20:27-33. [PubMed: 9934846]

159. Rose ML, Rusyn I, Bojes HK, Germolec DR, Luster M, Thurman RG. Role of Kupffer cells in peroxisome proliferator-induced hepatocyte proliferation. Drug Metab Rev. 1999; 31:87-116. [PubMed: 10065367]

160. Rusyn I, Rose ML, Bojes HK, Thurman RG. Novel role of oxidants in the molecular mechanism of action of peroxisome proliferators. Antiox Redox Signal. 2000; 2:607-621.

161. Flavell DM, Pineda T, Jamshidi IY, Evans D, Diamond JR, Elkeles RS, Bujac SR, Miller G, Talmud PJ, Staels B, Humphries SE. Variation in the PPARalpha gene is associated with altered function in vitro and plasma lipid concentrations in Type II diabetic subjects. Diabetologia. 2000; 43:673-680. [PubMed: 10855543]

162. Lacquemant C, Lepretre F, Pineda T, Manraj IM, Charpentier G, Ruiz J, Staels B, Froguel P. Mutation screening of the PPARalpha gene in type 2 diabetes associated with coronary heart disease. Diabetes Metab. 2000; 26:393-401. [PubMed: 11119019]

163. Tai ES, Demissie S, Cupples LA, Corella D, Wilson PW, Schaefer EJ, Ordovas JM. Association between the PPARA L162V polymorphism and plasma lipid levels: the Framingham Offspring Study. Arterioscler Thromb Vasc Biol. 2002; 22:805-810. [PubMed: 12006394]

164. Sapone A, Peters JM, Sakai S, Tomita S, Papiha SS, Dai R, Friedman FK, Gonzalez FJ. The human peroxisome proliferator-activated receptor alpha gene: identification and functional characterization of two natural allelic variants. Pharmacogenetics. 2000; 10:321-333. [PubMed: 10862523]

165. Yamakawa-Kobayashi K, Ishiguro H, Arinami T, Miyazaki R, Hamaguchi H. A Val227Ala polymorphism in the peroxisome proliferator activated receptor alpha (PPARalpha) gene is associated with variations in serum lipid levels. J Med Genet. 2002; 39:189-191. [PubMed: 11897821]

166. Chan E, Tan CS, Deurenberg-Yap M, Chia KS, Chew SK, Tai ES. The V227A polymorphism at the PPARA locus is associated with serum lipid concentrations and modulates the association between dietary polyunsaturated fatty acid intake and serum high density lipoprotein concentrations in Chinese women. Atherosclerosis. 2006; 187:309-315. [PubMed: 16288935]

167. Liu MH, Li J, Shen P, Husna B, Tai ES, Yong EL. A natural polymorphism in peroxisome proliferator-activated receptor-alpha hinge region attenuates transcription due to defective release of nuclear receptor corepressor from chromatin. Mol Endocrinol. 2008; 22:1078-1092. [PubMed: 18292238]

168. James NH, Gill JH, Brindle R, Woodyatt NJ, Macdonald N, Rolfe M, Hasmall SC, Tugwood JD, Holden PR, Roberts RA. Peroxisome proliferator-activated receptor (PPAR) a-regulated growth responses and their importance to hepatocarcinogenesis. Toxicol Lett. 1998; 102-103:91-96.

169. Lyche JL, Gutleb AC, Bergman A, Eriksen GS, Murk AJ, Ropstad E, Saunders M, Skaare JU. Reproductive and developmental toxicity of phthalates. J Toxicol Environ Health B Crit Rev. 2009; 12:225-249. [PubMed: 20183522]

170. Toppari J, Virtanen HE, Main KM, Skakkebaek NE. Cryptorchidism and hypospadias as a sign of testicular dysgenesis syndrome (TDS): environmental connection. Birth Defects Res A Clin Mol Teratol. 2010; 88:910-919. [PubMed: 20865786]

171. Sathyanarayana S. Phthalates and children's health. Curr Prob Pediatr Adolesc Health Care. 2008; 38:34-49.

172. Stefanini S, Serafini B, Nardacci R, Vecchioli SF, Moreno S, Sartori C. Morphometric analysis of liver and kidney peroxisomes in lactating rats and their pups after treatment with the peroxisomal proliferator di-(2-ethylhexyl)phthalate. Biol Cell. 1995; 85:167-176. [PubMed: 8785518]

173. Maranghi F, Lorenzetti S, Tassinari R, Moracci G, Tassinari V, Marcoccia D, Di Viglio A, Eusepi A, Romeo A, Magrelli A, Salvatore M, Tosto F, Viganotti M, Antoccia A, Di Masi A, Azzalin G, 
Tanzarella C, Macino G, Taruscio D, Mantovani A. In utero exposure to di-(2-ethylhexyl) phthalate affects liver morphology and metabolism in post-natal CD-1 mice. Reprod Toxicol. 2010; 29:427-432. [PubMed: 20307648]

174. Pak VM, Nailon RE, McCauley LA. Controversy: neonatal exposure to plasticizers in the NICU. MCN Am J Matern Child Nurs. 2007; 32:244-249. [PubMed: 17667290]

175. Jaakkola JJ, Knight TL. The role of exposure to phthalates from polyvinyl chloride products in the development of asthma and allergies: a systematic review and meta-analysis. Environ Health Perspect. 2008; 116:845-853. [PubMed: 18629304]

176. Hoppin JA, Ulmer R, London SJ. Phthalate exposure and pulmonary function. Environ Health Perspect. 2004; 112:571-574. [PubMed: 15064163]

177. Klimisch HJ, Gamer AO, Hellwig J, Kaufmann W, Jackh R. Di-(2-ethylhexyl) phthalate: a shortterm repeated inhalation toxicity study including fertility assessment. Food Chem Toxicol. 1992; 30:915-919. [PubMed: 1473784]

178. Doelman CJ, Borm PJ, Bast A. Plasticisers and bronchial hyperreactivity. Lancet. 1990; 335:725. [PubMed: 1969080]

179. Pan G, Hanaoka T, Yoshimura M, Zhang S, Wang P, Tsukino H, Inoue K, Nakazawa H, Tsugane $\mathrm{S}$, Takahashi K. Decreased serum free testosterone in workers exposed to high levels of di-nbutyl phthalate (DBP) and di-2-ethylhexyl phthalate (DEHP): a cross-sectional study in China. Environ Health Perspect. 2006; 114:1643-1648. [PubMed: 17107847]

180. Rozati R, Reddy PP, Reddanna P, Mujtaba R. Role of environmental estrogens in the deterioration of male factor fertility. Fertil Steril. 2002; 78:1187-1194. [PubMed: 12477510]

181. Zhang YH, Zheng LX, Chen BH. Phthalate exposure and human semen quality in Shanghai: a cross-sectional study. Biomed Environ Sci. 2006; 19:205-209. [PubMed: 16944777]

182. Hauser R, Meeker JD, Singh NP, Silva MJ, Ryan L, Duty S, Calafat AM. DNA damage in human sperm is related to urinary levels of phthalate monoester and oxidative metabolites. Hum Reprod. 2007; 22:688-695. [PubMed: 17090632]

183. Meeker JD, Calafat AM, Hauser R. Urinary metabolites of di(2-ethylhexyl) phthalate are associated with decreased steroid hormone levels in adult men. J Androl. 2009; 30:287-297. [PubMed: 19059903]

184. Colon I, Caro D, Bourdony CJ, Rosario O. Identification of phthalate esters in the serum of young Puerto Rican girls with premature breast development. Environ Health Perspect. 2000; 108:895900. [PubMed: 11017896]

185. Cobellis L, Latini G, De Felice C, Razzi S, Paris I, Ruggieri F, Mazzeo P, Petraglia F. High plasma concentrations of di-(2-ethylhexyl)-phthalate in women with endometriosis. Hum Reprod. 2003; 18:1512-1515. [PubMed: 12832380]

186. Reddy BS, Rozati R, Reddy BV, Raman NV. Association of phthalate esters with endometriosis in Indian women. BJOG. 2006; 113:515-520. [PubMed: 16637895]

187. Kim SH, Chun S, Jang JY, Chae HD, Kim CH, Kang BM. Increased plasma levels of phthalate esters in women with advanced-stage endometriosis: a prospective case-control study. Fertil Steril. 2011; 95:357-359. [PubMed: 20797718]

188. Poon R, Lecavalier P, Mueller R, Valli VE, Procter BG, Chu I. Subchronic oral toxicity of di-noctyl phthalate and di(2-Ethylhexyl) phthalate in the rat. Food Chem Toxicol. 1997; 35:225-239. [PubMed: 9146736]

189. Howdeshell KL, Wilson VS, Furr J, Lambright CR, Rider CV, Blystone CR, Hotchkiss AK, Gray LE Jr. A mixture of five phthalate esters inhibits fetal testicular testosterone production in the sprague-dawley rat in a cumulative, dose-additive manner. Toxicol Sci. 2008; 105:153-165. [PubMed: 18411233]

190. Ishihara M, Itoh M, Miyamoto K, Suna S, Takeuchi Y, Takenaka I, Jitsunari F. Spermatogenic disturbance induced by di-(2-ethylhexyl) phthalate is significantly prevented by treatment with antioxidant vitamins in the rat. Int J Androl. 2000; 23:85-94. [PubMed: 10762434]

191. Moffit JS, Bryant BH, Hall SJ, Boekelheide K. Dose-dependent effects of sertoli cell toxicants 2,5-hexanedione, carbendazim, and mono-(2-ethylhexyl) phthalate in adult rat testis. Toxicol Pathol. 2007; 35:719-727. [PubMed: 17763286] 
192. Lahousse SA, Wallace DG, Liu D, Gaido KW, Johnson KJ. Testicular gene expression profiling following prepubertal rat mono-(2-ethylhexyl) phthalate exposure suggests a common initial genetic response at fetal and prepubertal ages. Toxicol Sci. 2006; 93:369-381. [PubMed: 16809437]

193. Richburg JH, Boekelheide K. Mono-(2-ethylhexyl) phthalate rapidly alters both Sertoli cell vimentin filaments and germ cell apoptosis in young rat testes. Toxicol Appl Pharmacol. 1996; 137:42-50. [PubMed: 8607140]

194. Ge RS, Chen GR, Tanrikut C, Hardy MP. Phthalate ester toxicity in Leydig cells: developmental timing and dosage considerations. Reprod Toxicol. 2007; 23:366-373. [PubMed: 17258888]

195. Ward JM, Diwan BA, Ohshima M, Hu H, Schuller HM, Rice JM. Tumor-initiating and promoting activities of di(2-ethylhexyl) phthalate in vivo and in vitro. Environ Health Perspect. 1986; 65:279-291. [PubMed: 3709454]

196. Ward JM, Konishi N, Diwan BA. Renal tubular cell or hepatocyte hyperplasia is not associated in B6C3F1 mice after transplacental initiation with N-nitrosoethylurea. Exp Pathol. 1990; 40:138.

197. Ohno S, Fujii Y, Usuda N, Murata F, Nagata T. Peroxisomal proliferation in rat kidney induced with DEHP. I. Numerical change by light microscopic morphometry. Acta Histochem Cytochem. $1982 ; 15: 40-57$.

198. Reubsaet FA, Veerkamp JH, Bruckwilder ML, Trijbels JM, Monnens LA. Peroxisomal oxidases and catalase in liver and kidney homogenates of normal and di(ethylhexyl)phthalate-fed rats. Int J Biochem. 1991; 23:961-967. [PubMed: 1773902]

199. Lington AW, Bird MG, Plutnick RT, Stubbefield WA, Scala RA. Chronic toxicity and carcinogenic evaluation of diisononyl phthalate in rats. Fundam Appl Toxicol. 1997; 36:79-89. [PubMed: 9073470]

200. Jepsen KF, Abildtrup A, Larsen ST. Monophthalates promote IL-6 and IL-8 production in the human epithelial cell line A549. Toxicol In Vitro. 2004; 18:265-269. [PubMed: 15046772]

201. Glue C, Millner A, Bodtger U, Jinquan T, Poulsen LK. In vitro effects of monophthalates on cytokine expression in the monocytic cell line THP-1 and in peripheral blood mononuclear cells from allergic and non-allergic donors. Toxicol In Vitro. 2002; 16:657-662. [PubMed: 12423647]

202. Glue C, Platzer MH, Larsen ST, Nielsen GD, Skov PS, Poulsen LK. Phthalates potentiate the response of allergic effector cells. Basic Clin Pharmacol Toxicol. 2005; 96:140-142. [PubMed: 15679477]

203. Larsen ST, Hansen JS, Thygesen P, Begtrup M, Poulsen OM, Nielsen GD. Adjuvant and immuno-suppressive effect of six monophthalates in a subcutaneous injection model with BALB/ c mice. Toxicology. 2001; 169:37-51. [PubMed: 11696408]

204. Larsen ST, Nielsen GD. The adjuvant effect of di-(2-ethylhexyl) phthalate is mediated through a PPARalpha-independent mechanism. Toxicol Lett. 2007; 170:223-228. [PubMed: 17462839]

205. Dearman RJ, Beresford L, Bailey L, Caddick HT, Betts CJ, Kimber I. Di-(2-ethylhexyl) phthalate is without adjuvant effect in mice on ovalbumin. Toxicology. 2008; 244:231-241. [PubMed: 18179854]

206. Larsen ST, Hansen JS, Hammer M, Alarie Y, Nielsen GD. Effects of mono-2-ethylhexyl phthalate on the respiratory tract in BALB/c mice. Hum Exp Toxicol. 2004; 23:537-545. [PubMed: 15625780]

207. Bally MB, Opheim DJ, Shertzer HG. Di-(2-ethylhexyl) phthalate enhances the release of lysosomal enzymes from alveolar macrophages during phagocytosis. Toxicology. 1980; 18:4960. [PubMed: 7210023]

208. Nakamura R, Teshima R, Sawada J. Effect of dialkyl phthalates on the degranulation and Ca2+ response of RBL-2H3 mast cells. Immunol Lett. 2002; 80:119-124. [PubMed: 11750043]

209. Corton JC, Lapinskas PJ, Gonzalez FJ. Central role of PPARalpha in the mechanism of action of hepatocarcinogenic peroxisome proliferators. Mutat Res. 2000; 448:139-151. [PubMed: 10725468]

210. Reddy JK, Azarnoff DL, Hignite CE. Hypolipidaemic hepatic peroxisome proliferators form a novel class of chemical carcinogens. Nature. 1980; 283:397-398. [PubMed: 6766207] 
211. Marsman DS, Goldsworthy TL, Popp JA. Contrasting hepatocytic peroxisome proliferation, lipofuscin accumulation and cell turnover for the hepatocarcinogens $\mathrm{Wy}-14,643$ and clofibric acid. Carcinogenesis. 1992; 13:1011-1017. [PubMed: 1600604]

212. International Agency for Research on Cancer. Some industrial chemicals. IARC Press; Lyon, France: 2000.

213. Peters JM, Cattley RC, Gonzalez FJ. Role of PPAR alpha in the mechanism of action of the nongenotoxic carcinogen and peroxisome proliferator Wy-14,643. Carcinogenesis. 1997; 18:2029-2033. [PubMed: 9395198]

214. Grosse Y, Baan R, Secretan-Lauby B, Ghissassi F, Bouvard V, Benbrahim-Tallaa L, Guha N, Islami F, Galichet L, Straif K. WHO International Agency for Research on Cancer Monograph Working Group. . Carcinogenicity of chemicals in industrial and consumer products, food contaminants and flavourings, and water chlorination byproducts. Lancet Oncol. 2011; 12:328329. [PubMed: 21598447] 